\title{
Voltage-Gated Calcium Channels
}

\author{
William A. Catterall \\ Department of Pharmacology, University of Washington, Seattle, Washington 98195-7280 \\ Correspondence: wcatt@uw.edu
}

\begin{abstract}
Voltage-gated calcium $\left(\mathrm{Ca}^{2+}\right)$ channels are key transducers of membrane potential changes into intracellular $\mathrm{Ca}^{2+}$ transients that initiate many physiological events. There are ten members of the voltage-gated $\mathrm{Ca}^{2+}$ channel family in mammals, and they serve distinct roles in cellular signal transduction. The $\mathrm{Ca}_{\vee} 1$ subfamily initiates contraction, secretion, regulation of gene expression, integration of synaptic input in neurons, and synaptic transmission at ribbon synapses in specialized sensory cells. The Cav2 subfamily is primarily responsible for initiation of synaptic transmission at fast synapses. The Cav3 subfamily is important for repetitive firing of action potentials in rhythmically firing cells such as cardiac myocytes and thalamic neurons. This article presents the molecular relationships and physiological functions of these $\mathrm{Ca}^{2+}$ channel proteins and provides information on their molecular, genetic, physiological, and pharmacological properties.
\end{abstract}

\section{PHYSIOLOGICAL ROLES OF VOLTAGE-GATED $\mathrm{Ca}^{2+}$ CHANNELS}

$\mathrm{a}^{2+}$ channels in many different cell types Cactivate on membrane depolarization and mediate $\mathrm{Ca}^{2+}$ influx in response to action potentials and subthreshold depolarizing signals. $\mathrm{Ca}^{2+}$ entering the cell through voltagegated $\mathrm{Ca}^{2+}$ channels serves as the second messenger of electrical signaling, initiating many different cellular events (Fig. 1). In cardiac and smooth muscle cells, activation of $\mathrm{Ca}^{2+}$ channels initiates contraction directly by increasing cytosolic $\mathrm{Ca}^{2+}$ concentration and indirectly by activating calcium-dependent calcium release by ryanodine-sensitive $\mathrm{Ca}^{2+}$ release channels in the sarcoplasmic reticulum (Reuter 1979; Tsien 1983; Bers 2002). In skeletal muscle cells, voltage-gated $\mathrm{Ca}^{2+}$ channels in the transverse tubule membranes interact directly with ryanodine-sensitive $\mathrm{Ca}^{2+}$ release channels in the sarcoplasmic reticulum and activate them to initiate rapid contraction (Catterall 1991; Tanabe et al. 1993). The same $\mathrm{Ca}^{2+}$ channels in the transverse tubules also mediate a slow $\mathrm{Ca}^{2+}$ conductance that increases cytosolic concentration and thereby regulates the force of contraction in response to high-frequency trains of nerve impulses (Catterall 1991). In endocrine cells, voltage-gated $\mathrm{Ca}^{2+}$ channels mediate $\mathrm{Ca}^{2+}$ entry that initiates secretion of hormones (Yang and Berggren 2006). In neurons, voltage-gated $\mathrm{Ca}^{2+}$ channels initiate synaptic transmission (Tsien et al. 1988; Dunlap et al. 1995; Catterall and Few 2008). In many different cell types, $\mathrm{Ca}^{2+}$ entering the cytosol via voltage-gated $\mathrm{Ca}^{2+}$ channels regulates enzyme activity, gene expression, and other biochemical processes (Flavell and Greenberg 2008). Thus, voltage-gated $\mathrm{Ca}^{2+}$ channels are

Editors: Martin Bootman, Michael J. Berridge, James W. Putney, and H. Llewelyn Roderick

Additional Perspectives on Calcium Signaling available at www.cshperspectives.org

Copyright (C) 2011 Cold Spring Harbor Laboratory Press; all rights reserved; doi: 10.1101/cshperspect.a003947

Cite this article as Cold Spring Harb Perspect Biol 2011;3:a003947 
W.A. Catterall

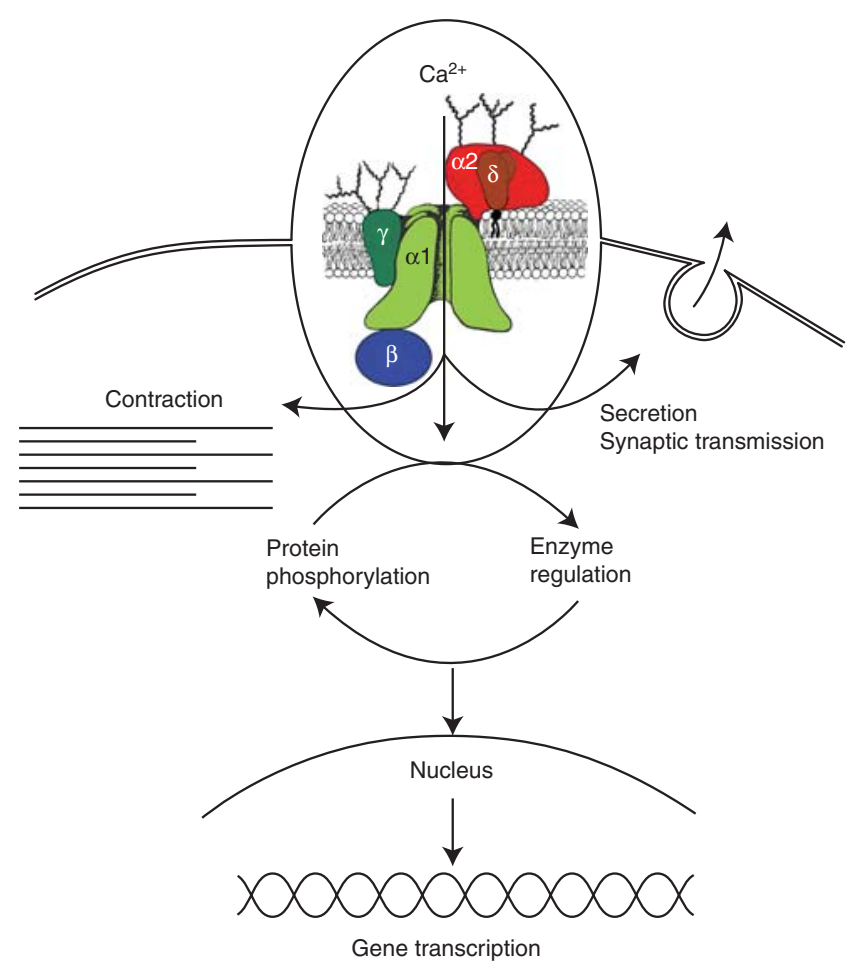

Figure 1. Signal transduction by voltage-gated $\mathrm{Ca}^{2+}$ channels. $\mathrm{Ca}^{2+}$ entering cells initiates numerous intracellular events, including contraction, secretion, synaptic transmission, enzyme regulation, protein phosphorylation/dephosphorylation, and gene transcription. (Inset) Subunit structure of voltage-gated $\mathrm{Ca}^{2+}$ channels. The five-subunit complex that forms high-voltage-activated $\mathrm{Ca}^{2+}$ channels is illustrated with a central poreforming $\alpha 1$ subunit, a disulfide-linked glycoprotein dimer of $\alpha 2$ and $\delta$ subunits, an intracellular $\beta$ subunit, and a transmembrane glycoprotein $\gamma$ subunit (in some $\mathrm{Ca}^{2+}$ channel subtypes). As described in the text, this model is updated from the original description of the subunit structure of skeletal muscle $\mathrm{Ca}^{2+}$ channels. (Adapted from Takahashi et al. 1987).

the key signal transducers of electrical excitability, converting the electrical signal of the action potential in the cell surface membrane to an intracellular $\mathrm{Ca}^{2+}$ transient. Signal transduction in different cell types involves different molecular subtypes of voltage-gated $\mathrm{Ca}^{2+}$ channels, which mediate voltage-gated $\mathrm{Ca}^{2+}$ currents with different physiological, pharmacological, and regulatory properties.

\section{$\mathrm{Ca}^{2+}$ CURRENT TYPES DEFINED BY PHYSIOLOGICAL AND PHARMACOLOGICAL PROPERTIES}

Since the first recordings of $\mathrm{Ca}^{2+}$ currents in cardiac myocytes (reviewed in Reuter 1979), it has become apparent that there are multiple types of $\mathrm{Ca}^{2+}$ currents as defined by physiological and pharmacological criteria (Tsien et al. 1988; Bean 1989a; Llinás et al. 1992). In cardiac, smooth, and skeletal muscle, the major $\mathrm{Ca}^{2+}$ currents are distinguished by high voltage of activation, large single channel conductance, slow voltage-dependent inactivation, marked up-regulation by cAMP-dependent protein phosphorylation pathways, and specific inhibition by $\mathrm{Ca}^{2+}$ antagonist drugs including dihydropyridines, phenylalkylamines, and benzothiazepines (Table 1) (Reuter 1979; Tsien et al. 1988). These $\mathrm{Ca}^{2+}$ currents have been designated L-type, as they have slow voltagedependent inactivation and therefore are long lasting when $\mathrm{Ba}^{2+}$ is the current carrier and there is no $\mathrm{Ca}^{2+}$-dependent inactivation (Tsien et al. 
Voltage-Gated Calcium Channels

\begin{tabular}{|c|c|c|c|c|}
\hline $\begin{array}{l}\mathrm{Ca}^{2+} \text { current } \\
\text { type }\end{array}$ & $\begin{array}{c}\alpha 1 \\
\text { Subunits }\end{array}$ & $\begin{array}{l}\text { Specific } \\
\text { blocker }\end{array}$ & Principal physiological functions & Inherited diseases \\
\hline \multirow[t]{4}{*}{$\mathrm{L}$} & $\mathrm{Ca}_{\mathrm{v}} 1.1$ & DHPs & $\begin{array}{l}\text { Excitation-contraction coupling in } \\
\text { skeletal muscle, regulation of } \\
\text { transcription }\end{array}$ & $\begin{array}{l}\text { Hypokalemic periodic } \\
\text { paralysis }\end{array}$ \\
\hline & $\mathrm{Ca}_{\mathrm{v}} 1.2$ & DHPs & $\begin{array}{l}\text { Excitation-contraction coupling in } \\
\text { cardiac and smooth muscle, } \\
\text { endocrine secretion, neuronal } \\
\mathrm{Ca}^{2+} \text { transients in cell bodies and } \\
\text { dendrites, regulation of enzyme } \\
\text { activity, regulation of transcription }\end{array}$ & $\begin{array}{l}\text { Timothy syndrome: cardiac } \\
\text { arrhythmia with } \\
\text { developmental } \\
\text { abnormalites and autism } \\
\text { spectrum disorders }\end{array}$ \\
\hline & $\mathrm{Ca}_{\mathrm{v}} 1.3$ & DHPs & $\begin{array}{l}\text { Endocrine secretion, cardiac } \\
\text { pacemaking, neuronal } \mathrm{Ca}^{2+} \\
\text { transients in cell bodies and } \\
\text { dendrites, auditory transduction }\end{array}$ & \\
\hline & $\mathrm{Ca}_{\mathrm{v}} 1.4$ & DHPs & Visual transduction & Stationary night blindness \\
\hline $\mathrm{N}$ & $\mathrm{Ca}_{\mathrm{v}} 2.1$ & $\omega$-CTx-GVIA & $\begin{array}{l}\text { Neurotransmitter release, } \\
\text { Dendritic } \mathrm{Ca}^{2+} \text { transients }\end{array}$ & \\
\hline $\mathrm{P} / \mathrm{Q}$ & $\mathrm{Ca}_{\mathrm{v}} 2.2$ & $\omega$-Agatoxin & $\begin{array}{l}\text { Neurotransmitter release, } \\
\text { Dendritic } \mathrm{Ca}^{2+} \text { transients }\end{array}$ & $\begin{array}{l}\text { Familial hemiplegic migraine, } \\
\text { cerebellar ataxia }\end{array}$ \\
\hline $\mathrm{R}$ & $\mathrm{Ca}_{\mathrm{v}} 2.3$ & SNX-482 & $\begin{array}{l}\text { Neurotransmitter release, } \\
\text { Dendritic } \mathrm{Ca}^{2+} \text { transients }\end{array}$ & \\
\hline \multirow[t]{3}{*}{$\mathrm{T}$} & $\mathrm{Ca}_{\mathrm{v}} 3.1$ & None & Pacemaking and repetitive firing & \\
\hline & $\mathrm{Ca}_{\mathrm{v}} 3.2$ & & Pacemaking and repetitive firing & Absence seizures \\
\hline & $\mathrm{Ca}_{\mathrm{v}} 3.3$ & & & \\
\hline
\end{tabular}

Abbreviations: DHP, dihydropyridine; $\omega$-CTx-GVIA, $\omega$-conotoxin GVIA from the cone snail Conus geographus; SNX-482, a synthetic version of a peptide toxin from the tarantula Hysterocrates gigas.

1988). L-type $\mathrm{Ca}^{2+}$ currents are also recorded in endocrine cells where they initiate release of hormones (Yang and Berggren 2006) and in neurons where they are important in regulation of gene expression, integration of synaptic input, and initiation of neurotransmitter release at specialized ribbon synapses in sensory cells (Tsien et al. 1988; Bean 1989a; Flavell and Greenberg 2008). L-type $\mathrm{Ca}^{2+}$ currents are subject to regulation by second messenger-activated protein phosphorylation in several cell types as discussed below.

Electrophysiological studies of $\mathrm{Ca}^{2+}$ currents in starfish eggs (Hagiwara et al. 1975) first revealed $\mathrm{Ca}^{2+}$ currents with different properties from L-type, and these were subsequently characterized in detail in voltage-clamped dorsal root ganglion neurons (Carbone and Lux 1984; Fedulova et al. 1985; Nowycky et al. 1985). In comparison to L-type, these novel $\mathrm{Ca}^{2+}$ currents activated at much more negative membrane potentials, inactivated rapidly, deactivated slowly, had small single channel conductance, and were insensitive to conventional $\mathrm{Ca}^{2+}$ antagonist drugs available at that time (Table 1). They were designated low-voltageactivated $\mathrm{Ca}^{2+}$ currents for their negative voltage dependence (Carbone and Lux 1984) or T-type $\mathrm{Ca}^{2+}$ currents for their transient openings (Nowycky et al. 1985).

Whole-cell voltage clamp and singlechannel recording from dissociated dorsal root ganglion neurons revealed an additional $\mathrm{Ca}^{2+}$ current, N-type (Table 1) (Nowycky et al. 1985). N-type $\mathrm{Ca}^{2+}$ currents were initially distinguished by their intermediate voltage dependence and rate of inactivation-more negative and faster than L-type but more positive and slower than T-type (Nowycky et al. 1985). They are insensitive to organic L-type $\mathrm{Ca}^{2+}$ channel blockers but blocked by the cone snail peptide $\omega$-conotoxin GVIA and related peptide 
W.A. Catterall

toxins (Tsien et al. 1988; Olivera et al. 1994). This pharmacological profile has become the primary method to distinguish $\mathrm{N}$-type $\mathrm{Ca}^{2+}$ currents, because the voltage dependence and kinetics of $\mathrm{N}$-type $\mathrm{Ca}^{2+}$ currents in different neurons vary considerably.

Analysis of the effects of other peptide toxins revealed three additional $\mathrm{Ca}^{2+}$ current types (Table 1). P-type $\mathrm{Ca}^{2+}$ currents, first recorded in Purkinje neurons (Llinás and Yarom 1981; Llinás et al. 1989), are distinguished by high sensitivity to the spider toxin $\omega$-agatoxin IVA (Mintz et al. 1992). Q-type $\mathrm{Ca}^{2+}$ currents, first recorded in cerebellar granule neurons (Randall and Tsien 1995), are blocked by $\omega$-agatoxin IVA with lower affinity. R-type $\mathrm{Ca}^{2+}$ currents in cerebellar granule neurons are resistant to most subtype-specific organic and peptide $\mathrm{Ca}^{2+}$ channel blockers (Randall and Tsien 1995) and may include multiple channel subtypes (Tottene et al. 1996). They can be blocked selectively in some cell types by the peptide SNX-482 derived from the tarantula Hysterocrates gigas (Newcomb et al. 1998). Although L-type and T-type $\mathrm{Ca}^{2+}$ currents are recorded in a wide range of cell types, N-, P-, Q-, and R-type $\mathrm{Ca}^{2+}$ currents are most prominent in neurons.

\section{MOLECULAR PROPERTIES OF $\mathrm{Ca}^{2+}$ CHANNELS}

\section{Subunit Structure}

$\mathrm{Ca}^{2+}$ channels purified from skeletal muscle transverse tubules are complexes of $\alpha 1, \alpha 2, \beta$, $\gamma$, and $\delta$ subunits (Fig. 1) (Curtis and Catterall 1984, 1986; Flockerzi et al. 1986; Hosey et al. 1987; Leung et al. 1987; Striessnig et al. 1987; Takahashi et al. 1987). Analysis of the biochemical properties, glycosylation, and hydrophobicity of these five subunits led to a model comprising a principal transmembrane $\alpha 1$ subunit of $190 \mathrm{kDa}$ in association with a disulfide-linked $\alpha 2 \delta$ dimer of $170 \mathrm{kDa}$, an intracellular phosphorylated $\beta$ subunit of $55 \mathrm{kDa}$, and a transmembrane $\gamma$ subunit of 33 kDa (Fig. 1) (Takahashi et al. 1987).

The $\alpha 1$ subunit is a protein of about 2000 amino acid residues in length with an amino acid sequence and predicted transmembrane structure like the previously characterized, pore-forming $\alpha$ subunit of voltage-gated sodium channels (Fig. 2) (Tanabe et al. 1987). The amino acid sequence is organized in four repeated domains (I-IV), which each contains six transmembrane segments $(\mathrm{S} 1-\mathrm{S} 6)$ and a

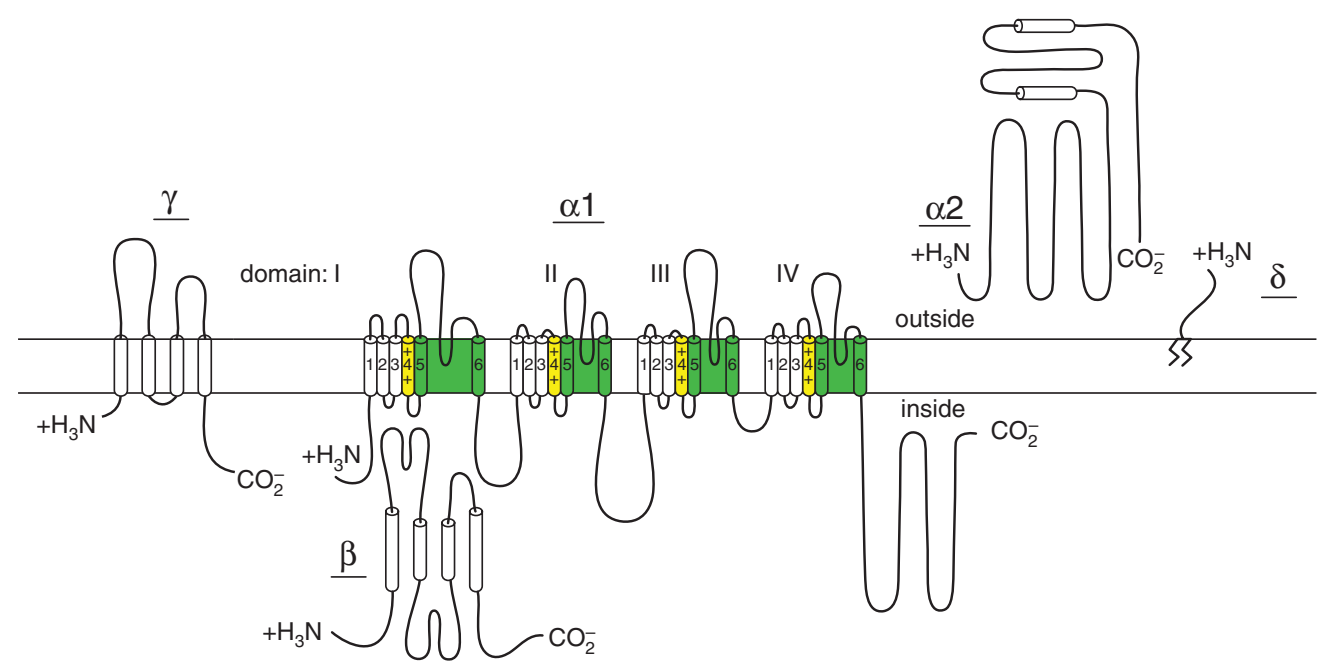

Figure 2. Subunit structure of $\mathrm{Ca}^{2+}$ channels. The structures of $\mathrm{Ca}^{2+}$ channel subunits are illustrated as transmembrane folding models; predicted $\alpha$ helices are depicted as cylinders; the lengths of lines correlate approximately to the lengths of the polypeptide segments represented; and the zigzag line on the $\delta$ subunit illustrates its glycophosphatidylinositol anchor. 
membrane-associated loop between transmembrane segments S5 and S6. As expected from biochemical analysis (Takahashi et al. 1987a), the intracellular $\beta$ subunit has predicted $\alpha$ helices but no transmembrane segments (Fig. 2) (Ruth et al. 1989), whereas the $\gamma$ subunit is a glycoprotein with four transmembrane segments (Fig. 2) (Jay et al. 1990). The cloned $\alpha 2$ subunit has many glycosylation sites and several hydrophobic sequences (Ellis et al. 1988), but biosynthesis studies indicate that it is an extracellular, extrinsic membrane glycoprotein, attached to the membrane through disulfide linkage to the $\delta$ subunit (Fig. 2) (Gurnett et al. 1996). The $\delta$ subunit is encoded by the $3^{\prime}$ end of the coding sequence of the same gene as the $\alpha 2$ subunit, and the mature forms of these two subunits are produced by posttranslational proteolytic processing and disulfide linkage (Fig. 2) (De Jongh et al. 1990). Although it was initially assumed that the $\delta$ subunit was anchored to the membrane via a single membrane segment, recent work argues persuasively that further posttranslational processing actually cleaves the predicted transmembrane segment and replaces it with a glycophosphatidylinositol membrane anchor (Fig. 2) (Davies et al. 2010).

Purification of cardiac $\mathrm{Ca}^{2+}$ channels labeled by dihydropyridine $\mathrm{Ca}^{2+}$ antagonists identified subunits of the sizes of the $\alpha 1, \alpha 2 \delta$, $\beta$, and $\gamma$ subunits of skeletal muscle $\mathrm{Ca}^{2+}$ channels (Chang and Hosey 1988; Schneider and Hofmann 1988; Kuniyasu et al. 1992), whereas immunoprecipitation of $\mathrm{Ca}^{2+}$ channels from neurons labeled by dihydropyridine $\mathrm{Ca}^{2+}$ antagonists revealed $\alpha 1, \alpha 2 \delta$, and $\beta$ subunits but no $\gamma$ subunit (Ahlijanian et al. 1990). Purification and immunoprecipitation of $\mathrm{N}$ type and $\mathrm{P} / \mathrm{Q}$-type $\mathrm{Ca}^{2+}$ channels labeled by $\omega$-conotoxin GVIA and $\omega$-agatoxin IVA, respectively, from brain membrane preparations also revealed $\alpha 1, \alpha 2 \delta$, and $\beta$ subunits but not $\gamma$ subunits (McEnery et al. 1991; Martin-Moutot et al. 1995; Witcher et al. 1995a; Liu et al. 1996). More recent experiments have unexpectedly revealed a novel $\gamma$ subunit (stargazin), which is the target of the stargazer mutation in mice (Letts et al. 1998), and a related series of seven $\gamma$ subunits is expressed in brain and other tissues (Klugbauer et al. 2000). These $\gamma$-subunit-like proteins can modulate the voltage dependence of $\mathrm{Ca}_{\mathrm{V}} 2.1$ channels expressed in nonneuronal cells, so they may be associated with these $\mathrm{Ca}^{2+}$ channels in vivo. However, the stargazin-like $\gamma$ subunits (also called transmembrane AMPA receptor modulators [TARPs]) are the primary modulators of glutamate receptors in the postsynaptic membranes of brain neurons (Nicoll et al. 2006), and it remains to be determined whether they are also associated with voltage-gated $\mathrm{Ca}^{2+}$ channels in brain neurons in vivo.

\section{Three-Dimensional Structure of $\mathrm{Ca}^{2+}$ Channels}

The three-dimensional structure of $\mathrm{Ca}^{2+}$ channels is not known at high resolution. Low-resolution structural models have been developed from image reconstruction analysis of $\mathrm{Ca}_{\mathrm{V}} 1.1$ channels purified from skeletal muscle membranes (Serysheva et al. 2002; Wang et al. 2002; Wolf et al. 2003), and some of the structural features have been associated with the $\alpha 1, \beta$, and $\alpha 2 \delta$ subunits (Fig. 3A). Further highresolution structural analysis will be required to confirm these initial structural models. The three-dimensional structure of the $\mathrm{Ca}_{\mathrm{V}} \beta$ subunits has been determined at high resolution by X-ray crystallography (Fig. 3B) (Chen et al. 2004; Van Petegem et al. 2004). These subunits contain conserved $\mathrm{SH} 3$ and guanylate kinase domains like the MAGUK family of scaffolding proteins. These two domains are arrayed side-by-side in the $\mathrm{Ca}_{\mathrm{V}} \beta$ subunit (Fig. 3B). The $\mathrm{Ca}_{\mathrm{V}} \beta$ subunits bind to a single site in the $\alpha 1$ subunits (the $\alpha$ interaction domain, AID) (Pragnell et al. 1994), which is located in the first half of the intracellular loop connecting domains I and II. The AID forms an $\alpha$ helix that is bound tightly to a groove in the guanylate kinase domain of the $\mathrm{Ca}_{\mathrm{V}} \beta$ subunit. This tight, multipoint binding interaction likely sustains the association between $\mathrm{Ca}^{2+}$ channel $\alpha 1$ and $\beta$ subunits throughout the lifetime of the $\mathrm{Ca}^{2+}$ channel complex at the cell surface membrane. MAGUK proteins often bind more than one protein partner, so $\mathrm{Ca}_{\mathrm{V}} \beta$ subunits may 
W.A. Catterall
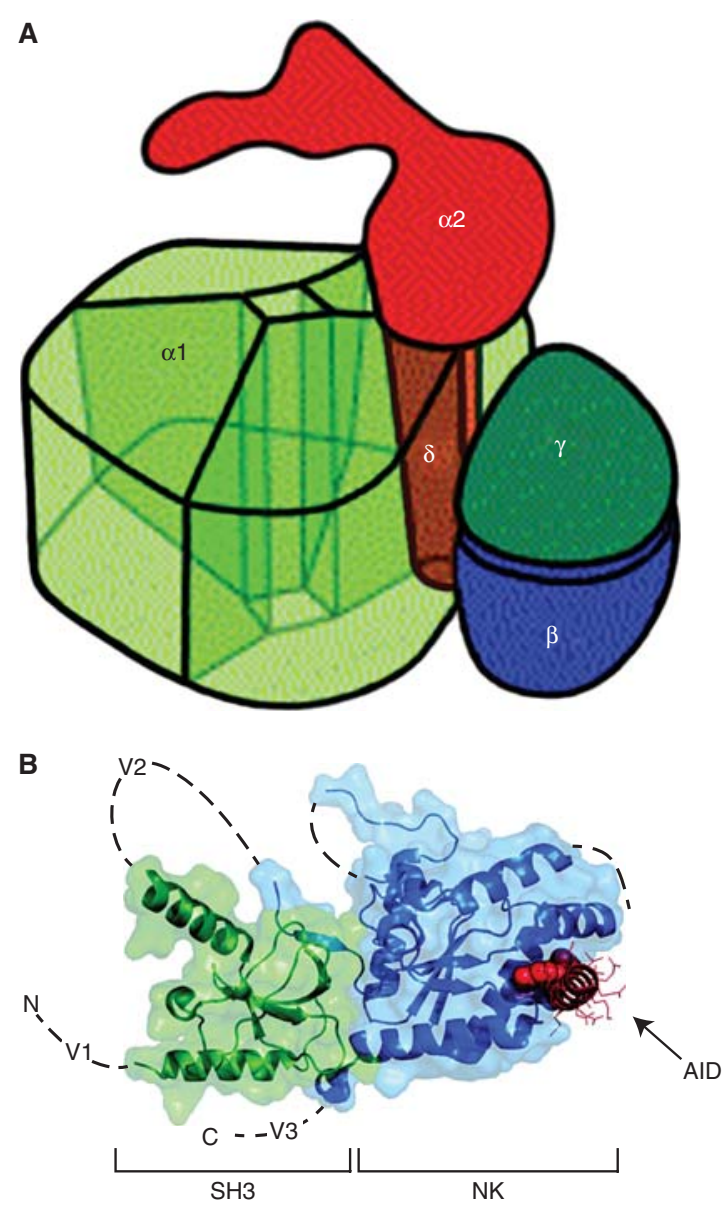

Figure 3. Three-dimensional architecture of $\mathrm{Ca}^{2+}$ channels. (A) Illustration of the skeletal muscle $\mathrm{Ca}_{\mathrm{V}} 1.1$ channel based on cryo-electronmicroscopy. This drawing assumes pseudo-fourfold symmetry of the $\alpha 1$ subunit. The view shows the extracellular side with the $\alpha 2$ subunit. The $\alpha 1, \gamma$, and $\delta$ subunits are embedded into the lipid membrane (not shown), which separates the extracellular $\alpha 2$ subunit from the cytosol. $\alpha 2$ is anchored via the disulfide-linked $\delta$ subunit within the $\alpha 1$ subunit. The proposed model allows for a tight interaction between $\alpha 1$ and $\delta$ as well as $\alpha 1$ and $\gamma$. (B) Structure of the $\mathrm{Ca}_{V} \beta$ subunit with the $\alpha$ interaction domain (AID). Coordinates are for the $\mathrm{Ca}_{\mathrm{V}} \beta 2 \mathrm{a}-\mathrm{Ca}_{\mathrm{V}} 1.2$ AID complex with $\mathrm{SH} 3$ (green) and NK (blue) domains are indicated. V1, V2, and V3 show the locations of the three variable domains that are absent from the structure. The AID (red) binds to a deep groove in the NK domain. AID residues tyrosine, tryptophan, and isoleucine are shown as CPK. The remaining residues are shown as lines.

also interact with other intracellular proteins, and several potential binding partners are under active investigation.

\section{Functions of $\mathrm{Ca}^{2+}$ Channel Subunits}

Expression of the $\alpha 1$ subunit is sufficient to produce functional skeletal muscle $\mathrm{Ca}^{2+}$ channels, but with low expression level and abnormal kinetics and voltage dependence of the $\mathrm{Ca}^{2+}$ current (Perez-Reyes et al. 1989). Coexpression of the $\alpha 2 \delta$ subunit and especially the $\beta$ subunit enhanced the level of expression and conferred more normal gating properties (Lacerda et al. 1991; Singer et al. 1991). As for skeletal muscle $\mathrm{Ca}^{2+}$ channels, coexpression of $\beta$ subunits has a large effect on the level of expression and the voltage dependence and kinetics of gating of 
cardiac and neuronal $\mathrm{Ca}^{2+}$ channels (reviewed in Hofmann et al. 1994; Dolphin 2003). In general, the level of expression is increased and the voltage dependence of activation and inactivation is shifted to more negative membrane potentials, and the rate of inactivation is increased. However, these effects are different for the individual $\beta$ subunit isoforms. For example, the $\beta 2$ a subunit slows channel inactivation in most subunit combinations. Coexpression of $\alpha 2 \delta$ subunits also increases expression and enhances function of $\mathrm{Ca}^{2+}$ channels, but to a lesser extent and in a more channel-specific way than do $\beta$ subunits (Arikkath and Campbell 2003; Davies et al. 2007). In general, $\gamma$ subunits have smaller effects.

\section{$\mathrm{Ca}^{2+}$ Channel Diversity}

The different types of $\mathrm{Ca}^{2+}$ currents are primarily defined by different $\alpha 1$ subunits, and ten different ones have been characterized by cDNA cloning and functional expression in mammalian cells or Xenopus oocytes (Table 1). These subunits can be divided into three structurally and functionally related families $\left(\mathrm{Ca}_{\mathrm{V}} 1, \mathrm{Ca}_{\mathrm{V}} 2\right.$, and $\mathrm{Ca}_{\mathrm{V}} 3$ ) (Snutch and Reiner 1992; Ertel et al. 2000). L-type $\mathrm{Ca}^{2+}$ currents are mediated by the $\mathrm{Ca}_{\mathrm{V}} 1$ type of $\alpha 1$ subunits, which have about $75 \%$ amino acid sequence identity among them. The $\mathrm{Ca}_{\mathrm{V}} 2$ type $\mathrm{Ca}^{2+}$ channels form a distinct subfamily with $<40 \%$ amino acid sequence identity with $\mathrm{Ca}_{\mathrm{V}} 1 \alpha 1$ subunits but $>70 \%$ amino acid sequence identity among themselves. Cloned $\mathrm{Ca}_{\mathrm{V}} 2.1$ subunits (Mori et al. 1991; Starr et al. 1991) conduct Por Q-type $\mathrm{Ca}^{2+}$ currents, which are inhibited by $\omega$-agatoxin IVA. $\mathrm{Ca}_{\mathrm{V}} 2.2$ subunits conduct $\mathrm{N}$-type $\mathrm{Ca}^{2+}$ currents blocked with high affinity by $\omega$-conotoxin GVIA (Dubel et al. 1992; Williams et al. 1992). Cloned $\mathrm{Ca}_{\mathrm{V}} 2.3$ subunits form R-type $\mathrm{Ca}^{2+}$ channels, which are resistant to both organic $\mathrm{Ca}^{2+}$ antagonists specific for L-type $\mathrm{Ca}^{2+}$ currents and the peptide toxins specific for N-type or P/Q-type $\mathrm{Ca}^{2+}$ currents (Soong et al. 1994). T-type $\mathrm{Ca}^{2+}$ currents are mediated by the $\mathrm{Ca}_{\mathrm{v}} 3 \mathrm{Ca}^{2+}$ channels (PerezReyes et al. 1998). These $\alpha 1$ subunits are only distantly related to the other known homologs, with $<25 \%$ amino acid sequence identity. These results reveal a surprising structural dichotomy between the T-type, low-voltageactivated $\mathrm{Ca}^{2+}$ channels and the high-voltageactivated $\mathrm{Ca}^{2+}$ channels. Evidently, these two lineages of $\mathrm{Ca}^{2+}$ channels diverged very early in evolution of multicellular organisms. Single representatives of the $\mathrm{Ca}_{\mathrm{V}} 1, \mathrm{Ca}_{\mathrm{V}} 2$, and $\mathrm{Ca}_{\mathrm{V}} 3$ subfamilies are present in invertebrate genomes, including the worm Caenorhabditis elegans and the fruit fly Drosophila.

The diversity of $\mathrm{Ca}^{2+}$ channel structure and function is substantially enhanced by multiple $\beta$ subunits. Four $\beta$ subunit genes have been identified, and each is subject to alternative splicing to yield additional isoforms (reviewed in Hofmann et al. 1994; Dolphin 2003). In $\mathrm{Ca}^{2+}$ channel preparations isolated from brain, individual $\mathrm{Ca}^{2+}$ channel $\alpha 1$ subunit types are associated with multiple types of $\beta$ subunits, although there is a different rank order in each case (Pichler et al. 1997; Witcher et al. 1995b). The different $\beta$ subunit isoforms cause different shifts in the kinetics and voltage dependence of gating, so association with different $\beta$ subunits can substantially alter the physiological function of an $\alpha 1$ subunit. Genes encoding four $\alpha 2 \delta$ subunits have been described (Klugbauer et al. 1999 ), and the $\alpha 2 \delta$ isoforms produced by these different genes have selective effects on the level of functional expression and the voltage dependence of different $\alpha 1$ subunits (Davies et al. 2007).

\section{Molecular Basis for $\mathrm{Ca}^{2+}$ Channel Function}

Intensive studies of the structure and function of the related pore-forming subunits of $\mathrm{Na}^{+}$, $\mathrm{Ca}^{2+}$, and $\mathrm{K}^{+}$channels have led to identification of their principal functional domains (reviewed in Catterall 2000a,b; Yi and Jan 2000; Bichet et al. 2003; Yu et al. 2005). Each domain of the principal subunits consists of six transmembrane $\alpha$ helices $(\mathrm{S} 1-\mathrm{S} 6)$ and a membrane-associated loop between S5 and S6 (Fig. 2). The S4 segments of each homologous domain serve as the voltage sensors for activation, moving outward and rotating under the influence of the electric field and initiating a 
W.A. Catterall

conformational change that opens the pore. The S5 and S6 segments and the membrane-associated pore loop between them form the pore lining of the voltage-gated ion channels. The narrow external end of the pore is lined by the pore loop, which contains a pair of glutamate residues in each domain that are required for $\mathrm{Ca}^{2+}$ selectivity, a structural feature that is unique to $\mathrm{Ca}^{2+}$ channels (Heinemann et al. 1992). Remarkably, substitutions that add only three glutamate residues in the pore loops between the S5 and S6 segments in domains II, III, and IV of sodium channels are sufficient to confer $\mathrm{Ca}^{2+}$ selectivity (Heinemann et al. 1992; Sather and McCleskey 2003). The inner pore is lined by the S6 segments, which form the receptor sites for the pore-blocking $\mathrm{Ca}^{2+}$ antagonist drugs specific for L-type $\mathrm{Ca}^{2+}$ channels (Hockerman et al. 1997a,b). All Ca ${ }^{2+}$ channels share these general structural features, but the amino acid residues that confer high affinity for the organic $\mathrm{Ca}^{2+}$ antagonists used in therapy of cardiovascular diseases are present only in the $\mathrm{Ca}_{\mathrm{V}} 1$ family of $\mathrm{Ca}^{2+}$ channels, which conduct L-type $\mathrm{Ca}^{2+}$ currents.

\section{$\mathrm{Ca}_{V} 1 \mathrm{CHANNELS} \mathrm{AND}$ \\ EXCITATION-RESPONSE COUPLING}

$\mathrm{Ca}_{\mathrm{V}} 1$ channels serve to couple depolarization of the plasma membrane to a wide range of cellular responses (Fig. 1). Three widely studied examples are excitation-contraction coupling in muscle, excitation-transcription coupling in nerve and muscle, and excitation-secretion coupling in endocrine cells and at specialized ribbon synapses.

\section{Cav1 CHANNELS AND}

\section{EXCITATION-CONTRACTION COUPLING}

\section{Mechanisms of Excitation-Contraction Coupling}

$\mathrm{Ca}_{\mathrm{V}} 1$ channels initiate excitation-contraction coupling in skeletal, cardiac, and smooth muscle. There are striking mechanistic differences between excitation-contraction coupling in skeletal muscle and cardiac muscle. In skeletal muscle, entry of external $\mathrm{Ca}^{2+}$ is not required for initiation of contraction (Armstrong et al. 1972). Ca 1.1 channels in the transverse tubules are thought to interact directly with the ryanodine-sensitive $\mathrm{Ca}^{2+}$ release channels (RyR1) of the sarcoplasmic reticulum (Numa et al. 1990), as observed in high-resolution electron microscopy (Block et al. 1988), and the voltage-driven conformational changes in their voltage-sensing domains are thought to directly induce activation of RyR1 (Numa et al. 1990). Reconstitution of excitation-contraction coupling in myocytes from mutant mice requires both $\mathrm{Ca}_{\mathrm{V}} 1.1$ and RyR1 proteins and their relevant sites of protein-protein interaction (Tanabe et al. 1990; Nakai et al. 1998), and functional expression of the $\mathrm{Ca}_{\mathrm{V}} 1.1$ channel in skeletal muscle requires its RyR1 binding partner (Nakai et al. 1996).

In contrast to skeletal muscle, entry of $\mathrm{Ca}^{2+}$ is required for excitation-contraction coupling in cardiac myocytes, and $\mathrm{Ca}^{2+}$ entry via $\mathrm{Ca}_{\mathrm{V}} 1.2$ channels triggers activation of the RyR2 and initiates $\mathrm{Ca}^{2+}$-induced $\mathrm{Ca}^{2+}$-release, activation of actomyosin, and contraction (Fabiato 1983; Bers 2002). Release of $\mathrm{Ca}^{2+}$ from the sarcoplasmic reticulum via RyR2 greatly amplifies the cellular $\mathrm{Ca}^{2+}$ transient and is required for effective initiation of contraction. All three steps in the cascade of $\mathrm{Ca}^{2+}$ transport processes- $\mathrm{Ca}^{2+}$ entry via $\mathrm{Ca}_{\mathrm{V}} 1.2$ channels, $\mathrm{Ca}^{2+}$ release via $\mathrm{RyR}$, and $\mathrm{Ca}^{2+}$ uptake into the sarcoplasmic reticulum by SERCA $\mathrm{Ca}^{2+}$ pumps-are tightly regulated by second messenger signaling networks (Bers 2002). The section below considers the regulation of $\mathrm{Ca}_{\mathrm{V}} 1$ channels in excitation-contraction coupling.

\section{Regulation of Excitation-Contraction Coupling via Cav1 Channels}

As part of the flight-or-flight response, the rate and force of contraction of both skeletal and cardiac muscle are increased through the activity of the sympathetic nervous system. Release of catecholamines stimulates $\beta$-adrenergic receptors ( $\beta$-ARs), which increases the force of skeletal and cardiac muscle contraction and the heart rate (Reuter 1983; Tsien et al. 1986). In 
cardiac muscle, $\mathrm{Ca}^{2+}$ influx through $\mathrm{Ca}_{\mathrm{v}} 1.2$ channels is responsible for initiating excitation-contraction coupling, and increased $\mathrm{Ca}^{2+}$ channel activity via the PKA pathway is primarily responsible for the increase in contractility. $\mathrm{Ca}_{\mathrm{v}} 1.2$ channels are modulated by the $\beta$-adrenergic receptor/cAMP signaling. Activation of $\beta$-adrenergic receptors increases L-type $\mathrm{Ca}^{2+}$ currents through PKA-mediated phosphorylation of the $\mathrm{Ca}_{\mathrm{v}} 1.2$ channel protein and/or associated proteins (Tsien 1973; Reuter and Scholz 1977; Osterrieder et al. 1982; McDonald et al. 1994).

The pore-forming $\alpha 1$ subunit and the auxiliary $\beta$ subunits of skeletal muscle $\mathrm{Ca}_{\mathrm{V}} 1.1$ channels (Curtis and Catterall 1985; Flockerzi et al. 1986; Takahashi et al. 1987) and cardiac $\mathrm{Ca}_{\mathrm{V}} 1.2$ channels (Hell et al. 1993b; De Jongh et al. 1996; Haase et al. 1996; Puri et al. 1997) are phosphorylated by PKA. These $\alpha 1$ subunits are also truncated by proteolytic processing of the carboxy-terminal domain (Fig. 4) (De Jongh et al. 1989, 1991, 1996; Hulme et al. 2005). Voltage-dependent potentiation of $\mathrm{Ca}_{\mathrm{v}} 1.1$ channels on the $50-\mathrm{msec}$ time scale requires PKA phosphorylation (Sculptoreanu et al. 1993) as well as PKA anchoring via an A kinase anchoring protein (AKAP) (Johnson et al. 1994, 1997), suggesting close association of PKA and $\mathrm{Ca}^{2+}$ channels. A novel, plasma membrane-targeted AKAP (AKAP15) is associated with both $\mathrm{Ca}_{\mathrm{v}} 1.1$ channels (Gray et al. 1997, 1998) and $\mathrm{Ca}_{\mathrm{V}} 1.2$ channels (Hulme et al. 2003), and may mediate their regulation by PKA. This AKAP (also known as AKAP18 [Fraser et al. 1998]) binds to the carboxy-terminal domain of $\mathrm{Ca}_{\mathrm{v}} 1.1$ channels (Hulme et al. 2002) and Ca 1.2 channels (Hulme et al. 2003) via a novel modified leucine zipper interaction near the primary sites of PKA phosphorylation. Block of this interaction by competing peptides prevents PKA regulation of $\mathrm{Ca}^{2+}$ currents in intact skeletal and cardiac myocytes (Hulme et al. 2002, 2003, 2006b). These physiological results suggest that a $\mathrm{Ca}^{2+}$ channel signaling complex containing AKAP15 and PKA is formed in both skeletal and cardiac muscle, and this conclusion is supported by specific colocalization of these proteins in both skeletal and cardiac myocytes and specific coimmunoprecipitation of this complex from both tissues (Hulme et al. 2002, 2003, 2006a). Remarkably, block of kinase anchoring is as effective as block of kinase activity in preventing $\mathrm{Ca}_{\mathrm{v}} 1.1$ and $\mathrm{Ca}_{\mathrm{v}} 1.2$ channel regulation, consistent with the conclusion that PKA targeting via leucine zipper interactions is absolutely required for regulation of $\mathrm{Ca}_{\mathrm{v}} 1$ channels in intact skeletal and cardiac myocytes.

Proteolytic Processing and Regulation via the Carboxy-Terminal Domain

The distal carboxy-terminal domains of skeletal muscle and cardiac $\mathrm{Ca}^{2+}$ channels are proteolytically processed in vivo (Fig. 4B) (De Jongh et al. 1991, 1996). Nevertheless, the most prominent in vitro PKA phosphorylation sites of both proteins are located beyond the site of proteolytic truncation (Rotman et al. 1992, 1995; De Jongh et al. 1996; Mitterdorfer et al. 1996), and interaction of AKAP15 and PKA with the distal carboxy-terminal domain through a leucine zipper motif is required for regulation of cardiac $\mathrm{Ca}^{2+}$ channels in intact myocytes (Hulme et al. 2003). These results imply that the distal carboxy-terminal domain remains associated with the proteolytically processed cardiac $\mathrm{Ca}_{\mathrm{V}} 1.2$ channel, and this is supported by evidence that the distal carboxyl-terminus can bind to the truncated $\mathrm{Ca}_{\mathrm{V}} 1.1$ and $\mathrm{Ca}_{\mathrm{V}} 1.2$ channels in vitro (Gerhardstein et al. 2000; Gao et al. 2001; Hulme et al. 2005) and in transfected cells (Hulme et al. 2002; Hulme et al. 2006b). Moreover, formation of this complex dramatically inhibits cardiac $\mathrm{Ca}^{2+}$ channel function in intact mammalian cells (Hulme et al. 2006b). Deletion of the distal carboxy-terminal near the site of proteolytic processing increases $\mathrm{Ca}^{2+}$ channel activity (Wei et al. 1994; Hulme et al. 2006b). However, noncovalent association of the cleaved distal carboxy-terminal reduces channel activity more than 10-fold, to a level much below that of channels with an intact carboxyl-terminus (Hulme et al. 2006b). Thus, proteolytic processing produces an autoinhibited $\mathrm{Ca}^{2+}$ channel complex containing noncovalently bound distal 
W.A. Catterall

A

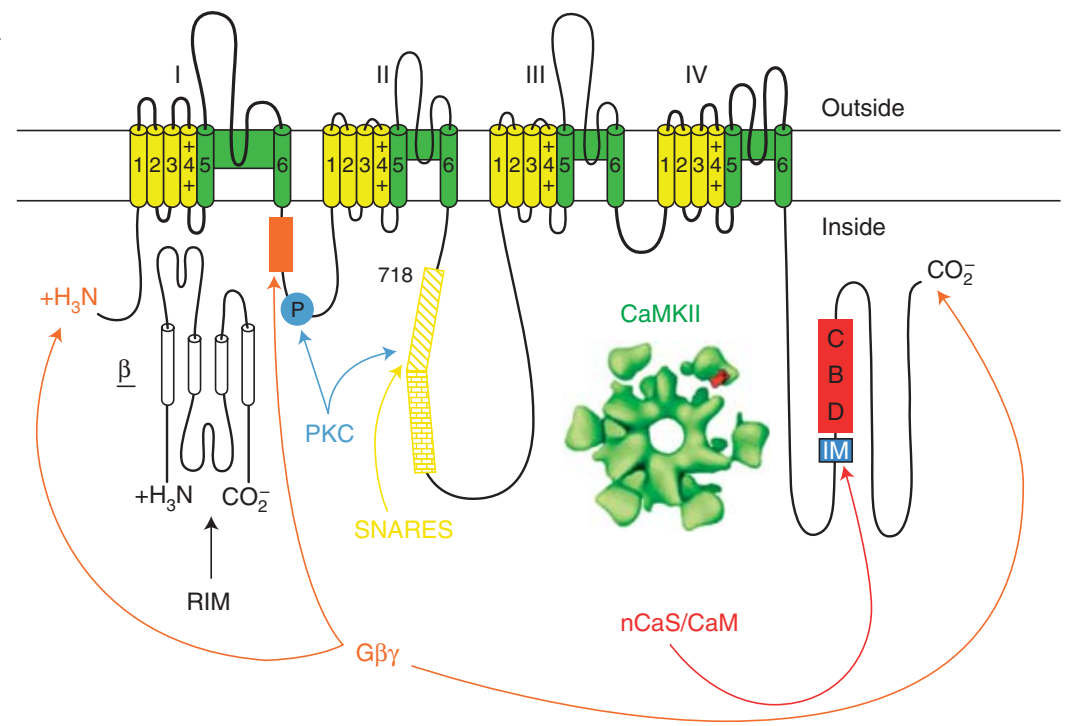

B

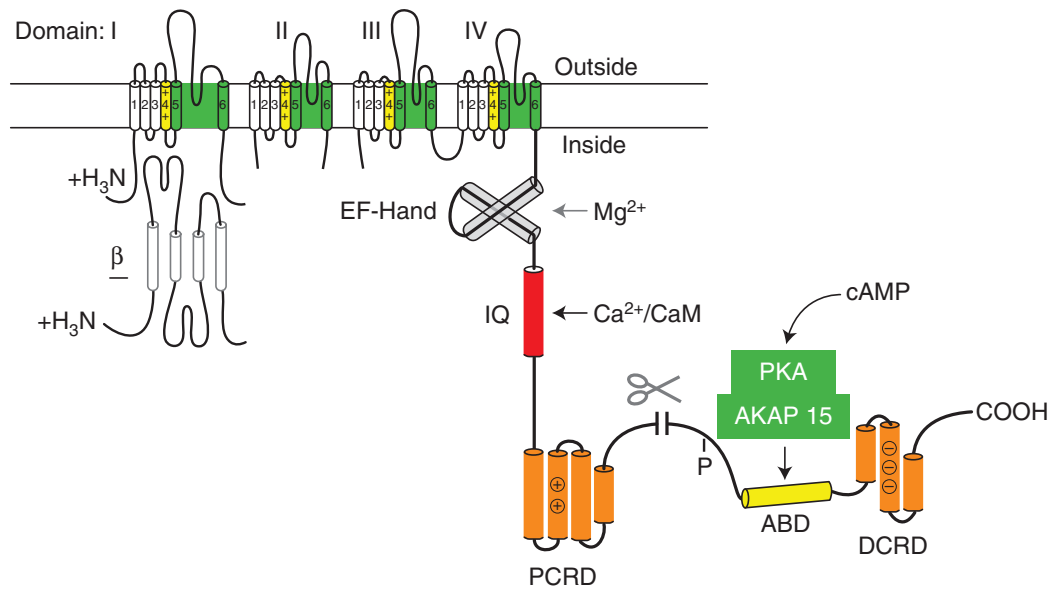

Figure 4. $\mathrm{Ca}^{2+}$ channel signaling complexes. (A) The presynaptic $\mathrm{Ca}^{2+}$ channel signaling complex. A presynaptic $\mathrm{Ca}^{2+}$ channel $\alpha 1$ subunit is illustrated as a transmembrane folding diagram as in Figure 2. Sites of interaction of SNARE proteins (the synprint site), Gß $\gamma$ subunits, protein kinase C (PKC), CaMKII, and CaM and CaS proteins are illustrated. IM, IQ-like motif; CBD, CaM binding domain. (B) The cardiac $\mathrm{Ca}^{2+}$ channel signaling complex. The carboxy-terminal domain of the cardiac $\mathrm{Ca}^{2+}$ channels is shown in expanded presentation to illustrate the regulatory interactions clearly. $\mathrm{ABD}$, AKAP15 binding domain; DCRD, distal carboxy-terminal regulatory domain; PCRD, proximal carboxy-terminal regulatory domain; scissors, site of proteolytic processing. The DCRD binds to the PCRD through a modified leucine zipper interaction.

carboxyl-terminus with AKAP15 and PKA associated through a modified leucine zipper interaction (Fig. 4B). This autoinhibited complex appears to be the primary substrate for regulation of cardiac $\mathrm{Ca}^{2+}$ channels by the $\beta$-adrenergic receptor/PKA pathway in vivo, and PKA up-regulation results from phosphorylation of a single site near the end of the proximal carboxy-terminal domain at the interface with the distal carboxy-terminal domain (Fig. 4B) (Hulme et al. 2006b; Emrick et al. 2010; Fuller et al. 2010). 


\section{$\mathrm{Ca}^{2+}$ Binding Proteins}

In addition to their regulation by the PKA/ AKAP15 signaling complex, cardiac $\mathrm{Ca}^{2+}$ channels have calmodulin bound to their carboxy-terminal domain through an IQ motif (Fig. 4B), and $\mathrm{Ca}^{2+}$ binding to calmodulin causes $\mathrm{Ca}^{2+}$-dependent inactivation (Peterson et al. 1999; Qin et al. 1999; Zühlke et al. 1999). Activation of $\mathrm{Ca}_{\mathrm{V}} 1.2$ channels in the presence of $\mathrm{Ba}^{2+}$ as the permeant ion results in inward $\mathrm{Ba}^{2+}$ currents that activate rapidly and inactivate slowly via a voltage-dependent inactivation process. In contrast, in the presence of $\mathrm{Ca}^{2+}$ as the permeant ion, $\mathrm{Ca}^{2+}$ currents are rapidly inactivated via $\mathrm{Ca}^{2+} /$ calmodulin-dependent inactivation. The $\mathrm{Ca}^{2+}$-dependent inactivation process is crucial for limiting $\mathrm{Ca}^{2+}$ entry during long cardiac action potentials. In light of these results, it is evident that both the cAMP and $\mathrm{Ca}^{2+}$ second messenger pathways regulate $\mathrm{Ca}_{\mathrm{V}} 1.2$ channels locally, dependent on associated regulatory proteins in $\mathrm{Ca}^{2+}$ channel signaling complexes.

\section{Cav1 CHANNELS IN EXCITATION- TRANSCRIPTION COUPLING}

$\mathrm{Ca}^{2+}$ entering neurons through L-type $\mathrm{Ca}^{2+}$ currents conducted by $\mathrm{Ca}_{\mathrm{V}} 1$ channels has a privileged role in regulation of gene transcription, compared to similar amounts of $\mathrm{Ca}^{2+}$ entering via other voltage-gated or ligand-gated ion channels (Flavell and Greenberg 2008). This unique access of $\mathrm{Ca}_{\mathrm{V}} 1$ channels to regulation of transcription might arise from preferential localization, which could provide $\mathrm{Ca}^{2+}$ in the vicinity of transcriptional regulators, preferential interaction with binding partners, which could be activated by local $\mathrm{Ca}^{2+}$ entry and carry the regulatory signal to the nucleus, or nuclear targeting of a subunit or domain of the $\mathrm{Ca}_{\mathrm{V}} 1$ channel itself, which would serve to regulate transcription directly. It is likely that all three of these mechanisms are involved based on recent experiments.

$\mathrm{Ca}_{\mathrm{V}} 1$ channels are localized in higher density in the cell bodies and proximal dendrites of neurons compared to $\mathrm{Ca}_{\mathrm{V}} 2$ and $\mathrm{Ca}_{\mathrm{V}} 3$ channels, which are more prevalent in nerve terminals and dendrites, respectively (Westenbroek et al. 1990; Hell et al. 1993a). This preferential localization would favor $\mathrm{Ca}^{2+}$ entry through these channels in control of transcription in the nucleus. However, this effect seems insufficient to fully account for the dominance of this $\mathrm{Ca}^{2+}$ entry pathway.

Studies with selective $\mathrm{Ca}^{2+}$ buffers indicate that only a local increase in $\mathrm{Ca}^{2+}$ is required for up-regulation of transcription in neurons (Wheeler et al. 2008). These findings suggest that specifically bound $\mathrm{Ca}^{2+}$-dependent regulatory proteins may respond to local $\mathrm{Ca}^{2+}$ entering via $\mathrm{Ca}_{\mathrm{V}} 1$ channels and regulate transcription. Calmodulin is a resident $\mathrm{Ca}^{2+}$ dependent regulator of $\mathrm{Ca}_{\mathrm{V}} 1$ channels (Pitt et al. 2001), and calmodulin binding to the proximal carboxy-terminal domain of $\mathrm{Ca}_{\mathrm{V}} 1.2$ channels is required for regulation of transcription in neurons (Bito et al. 1996; Dolmetsch et al. 2001). Thus, calmodulin itself might serve as a regulator by binding local $\mathrm{Ca}^{2+}$, changing conformation to the active form, and moving to the nucleus (Bito et al. 1996; Deisseroth et al. 1998). However, there are large pools of free and $\mathrm{Ca}^{2+}$-bound calmodulin throughout the cell, so additional mechanisms must be engaged to specifically move $\mathrm{Ca}^{2+} /$ calmodulin complexes from the $\mathrm{Ca}_{\mathrm{V}} 1$ channels to the nucleus in the context of this mode of regulation. Calcineurin bound to the distal carboxyterminal domain of $\mathrm{Ca}_{\mathrm{V}} 1$ channels also is a potential transcriptional regulator through dephosphorylation of regulatory proteins (Oliveria et al. 2007). In cultured hippocampal neurons, dephosphorylation of the nuclear factor of activated T cells (NFAT) by calcineurin bound to $\mathrm{Ca}_{\mathrm{V}} 1.2$ channels induces its dissociation, movement to the nucleus, and regulation of transcription (Oliveria et al. 2007). This pathway appears to have all of the necessary elements for selective regulation of gene transcription by $\mathrm{Ca}^{2+}$ entering neurons via $\mathrm{Ca}_{\mathrm{V}} 1.2$ channels and has the precedent that it is a crucial element in gene regulation in lymphocytes by a similar mechanism.

The distal carboxy-terminal domain of the $\mathrm{Ca}_{\mathrm{V}} 1$ channel itself has also been proposed as 
W.A. Catterall

a transcriptional regulator (Gomez-Ospina et al. 2006). The large carboxy-terminal domain of $\mathrm{Ca}_{\mathrm{V}} 1.1$ and $\mathrm{Ca}_{\mathrm{V}} 1.2$ channels is proteolytically processed in vivo near its center (De Jongh et al. 1991, 1996), leaving a noncovalently associated distal carboxy-terminal domain of more than 300 residues intact to regulate channel activity (Fig. 4B) (Hulme et al. 2006b). In neurons, this proteolytic cleavage process is regulated by $\mathrm{Ca}^{2+}$ and blocked by calpain inhibitors (Hell et al. 1996). The distal carboxyterminal domain can be detected in the nuclei of a subset of neurons in the developing brain and in neurons in cell culture (Gomez-Ospina et al. 2006), opening the possibility of direct effects on transcription in the nucleus. Indeed, the distal carboxy-terminal domain can regulate the transcription of a substantial set of other genes in neurons (Gomez-Ospina et al. 2006), as well as the transcription of the gene encoding the $\mathrm{Ca}_{\mathrm{V}} 1.2$ channel itself in cardiac myocytes (Schroder et al. 2009). This regulatory mechanism also has all of the necessary elements to give selective regulation of gene expression by $\mathrm{Ca}_{\mathrm{V}} 1.2$ channels, but it remains unknown how the parallel effects of the distal carboxylterminus on regulation of channel activity versus migration to the nucleus and regulation of transcription are controlled. At least in neurons, it seems that only a small fraction of the distal carboxy-terminal is located in the nucleus (Gomez-Ospina et al. 2006), so it may be that most of the proteolytically processed distal carboxy-terminal domain remains associated with $\mathrm{Ca}_{\mathrm{V}} 1.2$ channels as an autoinhibitory regulator of channel activity while a small fraction dissociates and moves to the nucleus to regulate transcription.

\section{$\mathrm{Ca}_{\mathbf{V}} 1 \mathrm{CHANNELS} \mathrm{IN}$ \\ EXCITATION-SECRETION COUPLING}

$\mathrm{Ca}^{2+}$ entry via $\mathrm{Ca}_{\mathrm{V}} 1$ channels initiates secretion of hormones from endocrine cells (Artalejo et al. 1994; Yang and Berggren 2006) and release of neurotransmitters at specialized ribbon synapses in sensory-transduction neurons (Table 1) (Kollmar et al. 1997; Barnes and Kelly 2002). The relative role of individual $\mathrm{Ca}_{\mathrm{V}} 1$ channel subtypes in secretion, as well as the contribution of $\mathrm{Ca}_{\mathrm{V}} 2$ channels, differs among cell types and species. In the pancreas, the requirement for L-type $\mathrm{Ca}^{2+}$ currents for insulin secretion is greater in mouse than in human $\beta$ cells (Eliasson et al. 2008; Braun et al. 2009). In adrenal chromaffin cells, L-type $\mathrm{Ca}^{2+}$ currents conducted by $\mathrm{Ca}_{\mathrm{V}} 1.2$ and $\mathrm{Ca}_{\mathrm{V}} 1.3$ channels trigger secretion of catecholamines, and their activity is strongly regulated by second messenger signaling pathways, including cAMP (Marcantoni et al. 2007).

Neurotransmitter release at specialized ribbon synapses is continuous, similar to hormone secretion in some physiological circumstances, and $\mathrm{Ca}_{\mathrm{V}} \mathrm{l}$ channels are specifically required for this mode of synaptic transmission. In photoreceptors, $\mathrm{Ca}_{\mathrm{V}} 1.4$ channels are primarily responsible for $\mathrm{Ca}^{2+}$ entry that triggers exocytosis of neurotransmitters (Table 1) (Barnes and Kelly 2002). Mutations in the $\mathrm{Ca}_{V} 1.4$ channel in humans lead to stationary night blindness (Bech-Hansen et al. 1998; Striessnig et al. 2010). In auditory hair cells, $\mathrm{Ca}_{\mathrm{V}} 1.3$ channels conduct the L-type $\mathrm{Ca}^{2+}$ currents that trigger neurotransmitter release (Kollmar et al. 1997). Deletion of the gene encoding $\mathrm{Ca}_{\mathrm{V}} 1.3$ channels causes deafness in mice (Platzer et al. 2000). The distal carboxy-terminal domain plays an autoregulatory role in both $\mathrm{Ca}_{\mathrm{V}} 1.3$ and $\mathrm{Ca}_{\mathrm{V}} 1.4$ channels (Singh et al. 2006, 2008), but it is not known whether it is subject to proteolytic processing in vivo. $\mathrm{Ca}_{\mathrm{V}} 1.3$ channels are regulated by multiple interacting proteins (Cui et al. 2007; Jenkins et al. 2010), which may be important in tuning their activity to fit the specific requirements of hair cells transmitting auditory information at different frequencies.

\section{Cav2 CHANNELS IN SYNAPTIC TRANSMISSION}

Presynaptic $\mathrm{Ca}^{2+}$ channels conduct P/Q-, N-, and R-type $\mathrm{Ca}^{2+}$ currents, which initiate synaptic transmission (Table 1). The efficiency of neurotransmitter release depends on the third or fourth power of the entering $\mathrm{Ca}^{2+}$. This steep dependence of neurotransmission on $\mathrm{Ca}^{2+}$ entry makes the presynaptic $\mathrm{Ca}^{2+}$ channel an 
Voltage-Gated Calcium Channels

exceptionally sensitive and important target of regulation. In the nervous system, $\mathrm{Ca}_{\mathrm{V}} 2.1$ channels conducting $\mathrm{P} / \mathrm{Q}$-type $\mathrm{Ca}^{2+}$ currents and $\mathrm{Ca}_{\mathrm{V}} 2.2$ channels conducting $\mathrm{N}$-type $\mathrm{Ca}^{2+}$ currents are the predominant pathways for $\mathrm{Ca}^{2+}$ entry initiating fast release of classical neurotransmitters like glutamate, acetylcholine, and GABA. Extensive studies indicate that they are controlled by many different protein interactions with their intracellular domains, which serve as a platform for $\mathrm{Ca}^{2+}$-dependent signal transduction (Fig. 4A).

\section{SNARE Proteins}

$\mathrm{Ca}^{2+}$ entry through voltage-gated $\mathrm{Ca}^{2+}$ channels initiates exocytosis by triggering the fusion of secretory vesicle membranes with the plasma membrane through actions on the SNARE protein complex of syntaxin, SNAP-25, and VAMP / synaptobrevin (reviewed in Bajjalieh and Scheller 1995; Sudhof 1995, 2004). The function of the SNARE protein complex is regulated by interactions with numerous proteins, including the synaptic vesicle $\mathrm{Ca}^{2+}$-binding protein synaptotagmin. Presynaptic $\mathrm{Ca}_{\mathrm{V}} 2.1$ and $\mathrm{Ca}_{\mathrm{V}} 2.2$ channels interact directly with the SNARE proteins through a specific synaptic protein interaction (synprint) site in the large intracellular loop connecting domains II and III (Fig. 4A) (Sheng et al. 1994; Rettig et al. 1996). This interaction is regulated by $\mathrm{Ca}^{2+}$ and protein phosphorylation (Sheng et al. 1996; Yokoyama et al. 1997, 2005). Synaptotagmin also binds to the synprint site of $\mathrm{Ca}_{\mathrm{V}} 2$ channels (Charvin et al. 1997; Sheng et al. 1997; Wiser et al. 1997). Injection into presynaptic neurons of peptides that block SNARE protein interactions with $\mathrm{Ca}_{\mathrm{V}} 2$ channels inhibits synaptic transmission, consistent with the conclusion that interaction with SNARE proteins is required to position docked synaptic vesicles near $\mathrm{Ca}^{2+}$ channels for fast exocytosis (Mochida et al. 1996; Rettig et al. 1997). These results define a second functional activity of the presynaptic $\mathrm{Ca}^{2+}$ channel-targeting docked synaptic vesicles to a source of $\mathrm{Ca}^{2+}$ for effective transmitter release.

In addition to this functional role of interaction between $\mathrm{Ca}^{2+}$ channels and SNARE proteins in the anterograde process of synaptic transmission, these interactions also have retrograde regulatory effects on $\mathrm{Ca}^{2+}$ channel function. Coexpression of the plasma membrane SNARE proteins syntaxin or SNAP-25 with $\mathrm{Ca}_{\mathrm{V}} 2.1$ or $\mathrm{Ca}_{\mathrm{V}} 2.2$ channels reduces the level of channel expression and inhibits $\mathrm{Ca}^{2+}$ channel activity by shifting the voltage dependence of steady-state inactivation during long depolarizing prepulses toward more negative membrane potentials (Bezprozvanny et al. 1995; Wiser et al. 1996; Zhong et al. 1999). The inhibitory effects of syntaxin are relieved by coexpression of SNAP-25 and synaptotagmin to form a complete SNARE complex (Wiser et al. 1997; Tobi et al. 1999; Zhong et al. 1999), which has the effect of enhancing activation of $\mathrm{Ca}_{\mathrm{V}} 2$ channels with nearby docked synaptic vesicles that have formed complete SNARE complexes and are ready for release. These processes fine-tune the efficiency of neurotransmitter release at frog neuromuscular junctions, where peptide and cDNA reagents can be used to modify synaptic function in vivo (Keith et al. 2007).

\section{G Protein Modulation}

$\mathrm{N}$-type and P/Q-type $\mathrm{Ca}^{2+}$ currents are regulated through multiple $\mathrm{G}$ protein coupled pathways (Hille 1994; Jones et al. 1997; Ikeda and Dunlap 1999). Although there are several G protein signaling pathways that regulate these channels, one common pathway that has been best studied at both cellular and molecular levels is voltage dependent and membrane delimited (i.e., a pathway without soluble intracellular messengers whose effects can be reversed by strong depolarization). Inhibition of $\mathrm{Ca}^{2+}$ channel activity is typically caused by a positive shift in the voltage dependence and a slowing of channel activation (Bean 1989b). These effects are relieved by strong depolarization resulting in facilitation of $\mathrm{Ca}^{2+}$ currents (Marchetti et al. 1986; Bean 1989b). Synaptic transmission is inhibited by neurotransmitters through this mechanism. G-protein $\alpha$ subunits are thought to confer specificity in receptor coupling, but $\mathrm{G} \beta \gamma$ subunits are responsible for modulation of $\mathrm{Ca}^{2+}$ channels. Cotransfection of cells with 
W.A. Catterall

the $\mathrm{Ca}^{2+}$ channel $\alpha 1$ and $\beta$ subunits plus $\mathrm{G} \beta \gamma$ causes a shift in the voltage dependence of $\mathrm{Ca}^{2+}$ channel activation to more positive membrane potentials and reduces the steepness of voltage-dependent activation, effects that closely mimic the actions of neurotransmitters and guanyl nucleotides on N-type and P/ Q-type $\mathrm{Ca}^{2+}$ channels in neurons and neuroendocrine cells (Herlitze et al. 1996). In contrast, transfection with a range of $\mathrm{G} \alpha$ subunits does not have this effect. This voltage shift can be reversed by strong positive prepulses resulting in voltage-dependent facilitation of the $\mathrm{Ca}^{2+}$ current in the presence of G $\beta \gamma$, again closely mimicking the effects of neurotransmitters and guanyl nucleotides on $\mathrm{Ca}^{2+}$ channels. Similarly, injection or expression of G $\beta \gamma$ subunits in sympathetic ganglion neurons induces facilitation and occludes modulation of N-type channels by norepinephrine, but $\mathrm{G} \alpha$ subunits do not (Herlitze et al. 1996; Ikeda 1996). These results point to the $G \beta \gamma$ subunits as the primary regulators of presynaptic $\mathrm{Ca}^{2+}$ channels via this voltage-dependent pathway through direct protein-protein interactions (Fig. 4A).

Possible sites of $\mathrm{G}$ protein $\beta \gamma$ subunit interaction with $\mathrm{Ca}^{2+}$ channels have been extensively investigated by construction and analysis of channel chimeras, by $\mathrm{G}$ protein binding experiments, and by site-directed mutagenesis and expression (Fig. 4A). Evidence from G protein binding and site-directed mutagenesis experiments points to the intracellular loop between domains I and II ( $\left.\mathrm{L}_{\mathrm{I}-\mathrm{II}}\right)$ as a crucial site of G protein regulation, and peptides from this region of $\mathrm{Ca}_{\mathrm{V}} 2.2$ prevent inhibition of channel activity by G $\beta \gamma$, presumably by binding to G $\beta \gamma$ and competitively inhibiting its access to $\mathrm{Ca}^{2+}$ channels (De Waard et al. 1997; Herlitze et al. 1997; Zamponi et al. 1997). This region of the channel binds G $\beta \gamma$ in vitro as well as in vivo in the yeast two-hybrid assay (De Waard et al. 1997; Zamponi et al. 1997; Garcia et al. 1998). Increasing evidence also points to segments in the amino- and carboxy-terminal domains of $\mathrm{Ca}^{2+}$ channels that are also required for $\mathrm{G}$ protein regulation (Zhang et al. 1996; Page et al. 1997, 1998; Qin et al. 1997; Canti et al. 1999; Li et al. 2004). As the amino- and carboxy-terminal domains are likely to interact with each other in the folded channel protein, a second site of interaction for $G$ proteins may be formed at their intersection.

\section{$\mathrm{Ca}^{2+}$ Binding Proteins}

$\mathrm{Ca}^{2+}$-dependent facilitation and inactivation of presynaptic $\mathrm{Ca}^{2+}$ channels was observed in patch clamp recordings of presynaptic nerve terminals in the rat neurohypophysis (Branchaw et al. 1997) and the calyx of Held synapse in the rat brainstem (Forsythe et al. 1998b). During tetanic stimulation at this synapse, $\mathrm{Ca}_{\mathrm{v}} 2.1$ channel currents show both $\mathrm{Ca}^{2+}$ dependent facilitation and inactivation (Borst and Sakmann 1998; Cuttle et al. 1998; Forsythe et al. 1998a), which results in facilitation and depression of excitatory postsynaptic responses (Borst and Sakmann 1998; Cuttle et al. 1998; Forsythe et al. 1998b). Ca ${ }^{2+}$-dependent facilitation and inactivation are also observed for cloned and expressed $\mathrm{Ca}_{\mathrm{v}} 2.1$ channels expressed in mammalian cells (Lee et al. 1999, 2000). A novel CaM-binding site was identified by yeast two-hybrid screening in the carboxy-terminal domain of the pore-forming $\alpha_{1} 2.1$ subunit of $\mathrm{Ca}_{\mathrm{v}} 2.1$ channels (Lee et al. 1999). This CaMbinding domain (CBD) (Fig. 4A) is located on the carboxy-terminal side of the sequence in $\alpha_{1} 2.1$ that corresponds to the IQ-domain that is required for CaM modulation of cardiac $\mathrm{Ca}_{\mathrm{v}} 1.2$ channels (Peterson et al. 1999; Qin et al. 1999; Zühlke et al. 1999). The modified IQ domain of $\alpha_{1} 2.1$ begins with the amino acid sequence IM instead of IQ and has other changes that would be predicted to substantially reduce its affinity for CaM. CaM binding to the $\mathrm{CBD}$ is $\mathrm{Ca}^{2+}$-dependent. Both $\mathrm{Ca}^{2+}$-dependent facilitation and inactivation are blocked by coexpression of a CaM inhibitor peptide (Lee et al. 1999), suggesting that $\mathrm{Ca}^{2+}$-dependent modulation of $\mathrm{Ca}_{\mathrm{v}} 2.1$ channels in neurons is caused by two sequential interactions with CaM or a related $\mathrm{Ca}^{2+}$-binding protein.

The mechanism for $\mathrm{Ca}^{2+}$-dependent facilitation and inactivation of $\mathrm{Ca}_{\mathrm{v}} 2.1$ channels involves CaM binding to two adjacent subsites - the CBD and the upstream IQ-like motif 
(Lee et al. 2003). The IQ-like motif is required for facilitation, whereas the $\mathrm{CBD}$ is required for inactivation. In addition, the two lobes of CaM are also differentially involved in these two processes. Mutation of the two EF hands in the carboxy-terminal lobe primarily prevents facilitation, whereas mutation of the EF hands in the amino-terminal lobe primarily prevents inactivation (DeMaria et al. 2001; Erickson et al. 2001; Lee et al. 2003). FRET studies indicate that apo-calmodulin can bind to $\mathrm{Ca}_{\mathrm{v}} 2.1$ channels in intact cells and binding is enhanced by $\mathrm{Ca}^{2+}$ binding to calmodulin (Erickson et al. 2001). Altogether, these results support a model in which the two lobes of CaM interact differentially with the modified IQ domain and the $\mathrm{CBD}$ to effect bi-directional regulation, with the high-affinity carboxy-terminal lobe primarily controlling facilitation through interactions with the IQ-like domain and the lower-affinity amino-terminal lobe primarily controlling inactivation through interactions with the CBD. This biphasic regulation of $\mathrm{Ca}_{\mathrm{V}} 2.1$ channels causes synaptic facilitation and depression in transfected sympathetic ganglion neuron synapses in which neurotransmission is initiated by transfected $\mathrm{Ca}_{\mathrm{V}} 2.1$ channels (Mochida et al. 2008).

$\mathrm{CaM}$ is the most well-characterized member of a superfamily of $\mathrm{Ca}^{2+}$ sensor $(\mathrm{CaS})$ proteins, many of which differ from $\mathrm{CaM}$ in having neuron-specific localization, amino-terminal myristoylation, and amino acid substitutions that prevent $\mathrm{Ca}^{2+}$ binding to one or two of the EF hands (Haeseleer and Palczewski 2002). The CaS protein $\mathrm{CaBP} 1$ binds to the $\mathrm{CBD}$, but not the IQ-like domain, of $\alpha_{1} 2.1$ and its binding is $\mathrm{Ca}^{2+}$-independent (Lee et al. 2002). CaBP1 causes a strong enhancement of the rate of inactivation, a positive shift in the voltagedependence of activation, and a loss of $\mathrm{Ca}^{2+}$ dependent facilitation of $\mathrm{Ca}_{\mathrm{v}} 2.1$ channels, which would combine to reduce the activity of these channels. Because it coimmunoprecipitates and colocalizes with $\mathrm{Ca}_{\mathrm{v}} 2.1$ channels in the brain (Lee et al. 2002), CaBP1 may be an important determinant of $\mathrm{Ca}_{\mathrm{v}} 2.1$ channel function in neurons and may contribute to the diversity of function of these channels in the nervous system. Visinin-like protein 2 (VILIP2) is a neuronal $\mathrm{Ca}^{2+}$-binding protein that is distantly related to CaBP-1 (Haeseleer and Palczewski 2002). Consistent with these structural differences, VILIP-2 has opposite effects on $\mathrm{Ca}_{\mathrm{V}} 2.1$ channels than CaBP-1 (Lautermilch et al. 2005). Coexpression of VILIP-2 causes slowed inactivation and enhanced facilitation, but its binding and effects are $\mathrm{Ca}^{2+}$-independent like CaBP-1. VILIP-2 may serve as a positive modulator of synaptic transmission, prolonging $\mathrm{Ca}^{2+}$ channel opening, and enhancing facilitation. Differential expression of CaBP1 and VILIP-2 at synapses would lead to opposite modulation of synaptic transmission in response to trains of action potentials and opposing input-output functions at the synapse.

\section{$\mathrm{Ca}_{\sqrt{ }} 3$ CHANNELS AND FREQUENCY MODULATION}

\section{Molecular Properties of Cav3 Channels}

$\mathrm{Ca}^{2+}$ channels of the $\mathrm{Ca}_{\mathrm{V}} 3$ subfamily conduct T-type $\mathrm{Ca}^{2+}$ currents (Catterall et al. 2005). These $\mathrm{Ca}^{2+}$ currents are activated at comparatively negative membrane potentials, in the same range as $\mathrm{Na}^{+}$currents in most cells, and they have fast voltage-dependent inactivation compared to other $\mathrm{Ca}^{2+}$ currents (Nowycky et al. 1985). These $\mathrm{Ca}^{2+}$ currents are therefore well-suited for rhythmic firing of action potentials. They are also well-suited for generation of large $\mathrm{Ca}^{2+}$ transients because they are activated at negative membrane potentials where the driving force for $\mathrm{Ca}^{2+}$ entry is large. A family of three $\mathrm{Ca}_{\mathrm{V}} 3$ channel $\alpha 1$ subunits have been characterized by cDNA cloning and sequencing (Catterall et al. 2005). Remarkably, these $\mathrm{Ca}^{2+}$ channel subunits have the same molecular organization as $\mathrm{Ca}_{\mathrm{V}} 1$ and $\mathrm{Ca}_{\mathrm{V}} 2$ channels but are only $\sim 25 \%$ identical in amino acid sequence (Catterall et al. 2005). This is a similar level of amino acid sequence identity as $\mathrm{Ca}^{2+}$ channels have with $\mathrm{Na}^{+}$channels, indicating that these subfamilies of $\mathrm{Ca}^{2+}$ channels separated from each other at the same point of evolution as $\mathrm{Na}^{+}$channels separated from $\mathrm{Ca}^{2+}$ channels. Although $\mathrm{Ca}_{\mathrm{V}} 3$ channels are similar 
W.A. Catterall

in structure to $\mathrm{Ca}_{\mathrm{V}} 1$ and $\mathrm{Ca}_{\mathrm{V}} 2$ channels, there is no clear evidence at present that they interact with the same set of auxiliary subunits. In fact, the prevailing view is that the $\alpha 1$ subunits function independently of other subunits. This would be unique among the families of $\mathrm{Na}^{+}$ and $\mathrm{Ca}^{2+}$ channels.

\section{Functional Roles of $\mathrm{Ca}_{\mathrm{V}} 3$ Channels}

As expected from their functional properties, $\mathrm{Ca}_{\mathrm{V}} 3$ channels are important in repetitively firing tissues. In the sino-atrial node of the heart, they conduct an important component of the pacemaker current that generates the heartbeat (Mangoni et al. 2006). In the relay neurons of the thalamus, they are crucial for generation of the rhythmic bursts of action potentials that drive sleep spindles and control sleep (Lee et al. 2004). Moreover, mutations in $\mathrm{Ca}_{\mathrm{V}} 3$ channels cause absence epilepsy, in which the affected individuals transiently enter a sleep-like state that interrupts their normal activities (Kim et al. 2001; Song et al. 2004). In the adrenal cortex, they are important in regulation of synthesis and secretion of aldosterone (Welsby et al. 2003).

\section{Regulation of Cav3 Channels}

In neurons, dopamine and other neurotransmitters inhibit T-type $\mathrm{Ca}^{2+}$ currents via a pathway that is specific for the G $\beta 2$ subunit (Wolfe et al. 2003). As for $\mathrm{Ca}_{\mathrm{V}} 2$ channels, $\mathrm{G}$ protein $\beta \gamma$ subunits bind directly to $\mathrm{Ca}_{\mathrm{V}} 3$ channels and regulate them (DePuy et al. 2006). The site of interaction is in the intracellular loop connecting domains II and III (DePuy et al. 2006). In addition, in adrenal glomerulosa cells, angiotensin II regulates aldosterone secretion via enhanced activation of $\mathrm{Ca}_{\mathrm{V}} 3.2$ channels (Welsby et al. 2003). This regulation is mediated by a signaling complex of CaMKII bound to the intracellular loop connecting domains II and III (Yao et al. 2006). Phosphorylation of a single serine residue in this intracellular loop negatively shifts the voltage dependence of activation and thereby substantially increases $\mathrm{Ca}^{2+}$ current at negative membrane potentials (Yao et al.
2006). It is unknown at this stage whether binding of CaMKII is required for physiological regulation or whether binding of the kinase per se has any regulatory effect.

\section{THE EFFECTOR CHECKPOINT MODEL OF $\mathrm{Ca}^{2+}$ CHANNEL REGULATION}

In closing this article on $\mathrm{Ca}^{2+}$ signaling via voltage-gated $\mathrm{Ca}^{2+}$ channels, it is interesting to introduce an emerging theme that unites several aspects of the localized regulation of these proteins. $\mathrm{Ca}^{2+}$ channel signaling complexes are formed when the effectors and regulators of the $\mathrm{Ca}^{2+}$ signal bind to the intracellular domains of $\mathrm{Ca}^{2+}$ channels to effectively receive and respond to the local $\mathrm{Ca}^{2+}$ signal. In four cases, binding of the effectors of the $\mathrm{Ca}^{2+}$ signal has been shown to enhance the activity of the $\mathrm{Ca}_{\mathrm{V}} 1$ and $\mathrm{Ca}_{\mathrm{V}} 2$ channels. First, in skeletal muscle, interactions of the plasma membrane $\mathrm{Ca}_{\mathrm{V}} 1.1$ channel with the ryanodine-sensitive $\mathrm{Ca}^{2+}$ release channel in the sarcoplasmic reticulum, which serves as the effector of excitation-contraction coupling, greatly increase the functional activity of the $\mathrm{Ca}_{\mathrm{V}} 1.1$ channels (Nakai et al. 1996a). Second, as described above, interaction with individual plasma membrane SNARE proteins inhibits the activity of $\mathrm{Ca}_{\mathrm{V}} 2$ channels, but formation of complete SNARE complex containing synaptotagmin, the effector of exocytosis, relieves this inhibition and enhances $\mathrm{Ca}^{2+}$ channel activity (Bezprozvanny et al. 1995; Wiser et al. 1996, 1997; Zhong et al. 1999). Third, binding of $\mathrm{Ca}^{2+} / \mathrm{CaM}-$ dependent protein kinase II, an effector of $\mathrm{Ca}^{2+}$-dependent regulatory events, to a site in the carboxy-terminal domain of $\mathrm{Ca}_{\mathrm{V}} 2.1$ channels substantially increases their activity (Jiang et al. 2008). Finally, binding of RIM, a regulator of SNARE protein function, to the $C a_{V} \beta$ subunits substantially increases $\mathrm{Ca}_{\mathrm{V}} 2$ channel activity (Kiyonaka et al. 2007). The common thread in all of these diverse examples of $\mathrm{Ca}^{2+}$ channel regulation by interacting proteins is that binding of an effector ready to respond to the $\mathrm{Ca}^{2+}$ signal enhances the activity of the $\mathrm{Ca}^{2+}$ channel. Thus, this mechanism provides a functional checkpoint of the fitness of a 
$\mathrm{Ca}^{2+}$ channel to carry out its physiological role, and enhances its activity if it passes this checkpoint criterion. This "effector checkpoint" mechanism would serve to focus $\mathrm{Ca}^{2+}$ entry on the $\mathrm{Ca}_{\mathrm{V}}$ channels that are ready to use the resulting $\mathrm{Ca}^{2+}$ signal to initiate a physiological intracellular signaling process. It seems likely that further studies will reveal more examples of this form of regulation and that it may be a unifying theme in the regulation of $\mathrm{Ca}^{2+}$ signaling by $\mathrm{Ca}_{\mathrm{V}}$ channels.

\section{REFERENCES}

Ahlijanian MK, Westenbroek RE, Catterall WA. 1990. Subunit structure and localization of dihydropyridinesensitive calcium channels in mammalian brain, spinal cord, and retina. Neuron 4: 819-832.

Arikkath J, Campbell KP. 2003. Auxiliary subunits: Essential components of the voltage-gated calcium channel complex. Curr Opin Neurobiol 13: 298-307.

Armstrong CM, Bezanilla FM, Horowicz P. 1972. Twitches in the presence of ethylene glycol bis (-aminoethyl ether)- $N, N^{\prime}$-tetracetic acid. Biochim Biophys Acta 267: 605-608.

Artalejo CR, Adams ME, Fox AP. 1994. Three types of calcium channel trigger secretion with different efficacies in chromaffin cells. Nature 367: 72-76.

Bajjalieh SM, Scheller RH. 1995. The biochemistry of neurotransmitter secretion. J Biol Chem 270: 1971-1974.

Barnes S, Kelly ME. 2002. Calcium channels at the photoreceptor synapse. Adv Exp Med Biol 514: 465-476.

Bean BP. 1989a. Classes of calcium channels in vertebrate cells. Annu Rev Physiol 51: 367-384.

Bean BP. 1989b. Neurotransmitter inhibition of neuronal calcium currents by changes in channel voltage dependence. Nature 340: 153-156.

Bech-Hansen NT, Naylor MJ, Maybaum TA, Pearce WG, Koop B, Fishman GA, Mets M, Musarella MA, Boycott KM. 1998. Loss-of-function mutations in a calciumchannel $\alpha 1$ subunit gene in Xp11.23 cause incomplete $\mathrm{X}$-linked congenital stationary night blindness. Nat Genet 19: 264-267.

Bers DM. 2002. Cardiac excitation-contraction coupling. Nature 415: 198-205.

Bezprozvanny I, Scheller RH, Tsien RW. 1995. Functional impact of syntaxin on gating of N-type and Q-type calcium channels. Nature 378: 623-626.

Bichet D, Haass FA, Jan LY. 2003. Merging functional studies with structures of inward-rectifier potassium channels. Nat Rev Neurosci 4: 957-967.

Bito H, Deisseroth K, Tsien RW. 1996. CREB phosphorylation and dephosphorylation: $\mathrm{A} \mathrm{Ca}^{2+}$ - and stimulus duration-dependent switch for hippocampal gene expression. Cell 87: 1203-1214.

Block BA, Imagawa T, Campbell KP, Franzini-Armstrong C. 1988. Structural evidence for direct interaction between the molecular components of the transverse tubule/sarcoplasmic reticulum junction in skeletal muscle. J Cell Biol 107: 2587-2600.

Borst JG, Sakmann B. 1998. Facilitation of presynaptic calcium currents in the rat brainstem. J Physiol 513: 149-155.

Branchaw JL, Banks MI, Jackson MB. 1997. $\mathrm{Ca}^{2+}$ - and voltage-dependent inactivation of $\mathrm{Ca}^{2+}$ channels in nerve terminals of the neurohypophysis. J Neurosci 17: 5772-5781.

Braun M, Ramracheya R, Johnson PR, Rorsman P. 2009. Exocytotic properties of human pancreatic $\beta$-cells. Ann NY Acad Sci 1152: 187-193.

Canti C, Page KM, Stephens GJ, Dolphin AC. 1999. Identification of residues in the $\mathrm{N}$ terminus of $\alpha 1 \mathrm{~B}$ critical for inhibition of the voltage-dependent calcium channel by G $\beta \gamma$. J Neurosci 19: 6855-6864.

Carbone E, Lux HD. 1984. A low voltage-activated, fully inactivating $\mathrm{Ca}$ channel in vertebrate sensory neurones. Nature 310: 501-502.

Catterall WA. 1991. Excitation-contraction coupling in vertebrate skeletal muscle: A tale of two calcium channels. Cell 64: 871-874.

Catterall WA. 2000a. From ionic currents to molecular mechanisms: The structure and function of voltage-gated sodium channels. Neuron 26: 13-25.

Catterall WA. 2000b. Structure and regulation of voltagegated calcium channels. Annu Rev Cell Dev Biol 16: 521-555.

Catterall WA, Few AP. 2008. Calcium channel regulation and presynaptic plasticity. Neuron 59: 882-901.

Catterall WA, Perez-Reyes E, Snutch TP, Striessnig J. 2005. International Union of Pharmacology. XLVIII. Nomenclature and structure-function relationships of voltagegated calcium channels. Pharmacol Rev 57: 411-425.

Chang FC, Hosey MM. 1988. Dihydropyridine and phenylalkylamine receptors associated with cardiac and skeletal muscle calcium channels are structurally different. J Biol Chem 263: 18929-18937.

Charvin N, Lévêque C, Walker D, Berton F, Raymond C, Kataoka M, Shoji-Kasai Y, Takahashi M, De Waard M, Seagar MJ. 1997. Direct interaction of the calcium sensor protein synaptotagmin I with a cytoplasmic domain of the $\alpha 1 \mathrm{~A}$ subunit of the $\mathrm{P} / \mathrm{Q}$-type calcium channel. EMBO J 16: 4591-4596.

Chen YH, Li MH, Zhang Y, He LL, Yamada Y, Fitzmaurice A, Shen Y, Zhang H, Tong L, Yang J. 2004. Structural basis of the $\alpha 1 \beta$ subunit interaction of voltage-gated $\mathrm{Ca}^{2+}$ channels. Nature 429: 675-680.

Cui G, Meyer AC, Calin-Jageman I, Neef J, Haeseleer F, Moser T, Lee A. 2007. $\mathrm{Ca}^{2+}$-binding proteins tune $\mathrm{Ca}^{2+}$ feedback to $\mathrm{Ca}_{\mathrm{v}} 1.3$ channels in mouse auditory hair cells. J Physiol 585: 791-803.

Curtis BM, Catterall WA. 1984. Purification of the calcium antagonist receptor of the voltage-sensitive calcium channel from skeletal muscle transverse tubules. Biochem 23: $2113-2118$.

Curtis BM, Catterall WA. 1985. Phosphorylation of the calcium antagonist receptor of the voltage-sensitive calcium channel by cAMP-dependent protein kinase. Proc Natl Acad Sci 82: 2528-2532. 
W.A. Catterall

Curtis BM, Catterall WA. 1986. Reconstitution of the voltage-sensitive calcium channel purified from skeletal muscle transverse tubules. Biochemistry 25: 3077-3083.

Cuttle MF, Tsujimoto T, Forsythe ID, Takahashi T. 1998. Facilitation of the presynaptic calcium current at an auditory synapse in rat brainstem. J Physiol 512: 723-729.

Davies A, Hendrich J, Van Minh AT, Wratten J, Douglas L, Dolphin AC. 2007. Functional biology of the $\alpha 2 \delta$ subunits of voltage-gated calcium channels. Trends Pharmacol Sci 28: 220-228.

Davies A, Kadurin I, Alvarez-Laviada A, Douglas L, Nieto-Rostro M, Bauer CS, Pratt WS, Dolphin AC. 2010. The $\alpha 2 \delta$ subunits of voltage-gated calcium channels form GPI-anchored proteins, a posttranslational modification essential for function. Proc Natl Acad Sci 107: $1654-1659$.

De Jongh KS, Merrick DK, Catterall WA. 1989. Subunits of purified calcium channels: A $212-\mathrm{kDa}$ form of $\alpha 1$ and partial amino acid sequence of a phosphorylation site of an independent $\beta$ subunit. Proc Natl Acad Sci 86: 8585-8589.

De Jongh KS, Warner C, Catterall WA. 1990. Subunits of purified calcium channels. $\alpha_{2}$ and $\delta$ are encoded by the same gene. J Biol Chem 265: 14738-14741.

De Jongh KS, Warner C, Colvin AA, Catterall WA. 1991. Characterization of the two size forms of the $\alpha 1$ subunit of skeletal muscle L-type calcium channels. Proc Natl Acad Sci 88: 10778-10782.

De Jongh KS, Murphy BJ, Colvin AA, Hell JW, Takahashi M, Catterall WA. 1996. Specific phosphorylation of a site in the full-length form of the $\alpha 1$ subunit of the cardiac L-type calcium channel by cAMP-dependent protein kinase. Biochemistry 35: 10392-10402.

De Waard M, Liu HY, Walker D, Scott VES, Gurnett CA, Campbell KP. 1997. Direct binding of G-protein $\beta \gamma$ complex to voltage-dependent calcium channels. Nature 385: $446-450$.

Deisseroth K, Heist EK, Tsien RW. 1998. Translocation of calmodulin to the nucleus supports CREB phosphorylation in hippocampal neurons. Nature 392: 198-202.

DeMaria CD, Soong TW, Alseikhan BA, Alvania RS, Yue DT. 2001. Calmodulin bifurcates the local $\mathrm{Ca}^{2+}$ signal that modulates P/Q-type $\mathrm{Ca}^{2+}$ channels. Nature 411: 484489.

DePuy SD, Yao J, Hu C, McIntire W, Bidaud I, Lory P, Rastinejad F, Gonzalez C, Garrison JC, Barrett PQ. 2006. The molecular basis for T-type $\mathrm{Ca}^{2+}$ channel inhibition by G protein $\beta 2 \gamma 2$ subunits. Proc Natl Acad Sci 103: 14590-14595.

Dolmetsch RE, Pajvani U, Fife K, Spotts JM, Greenberg ME. 2001. Signaling to the nucleus by an L-type calcium channel-calmodulin complex through the MAP kinase pathway. Science 294: 333-339.

Dolphin AC. 2003. $\beta$ subunits of voltage-gated calcium channels. J Bioenerg Biomembr 35: 599-620.

Dubel SJ, Starr TVB, Hell J, Ahlijanian MK, Enyeart JJ, Catterall WA, Snutch TP. 1992. Molecular cloning of the $\alpha 1$ subunit of an omega-conotoxin-sensitive calcium channel. Proc Natl Acad Sci 89: 5058-5062.
Dunlap K, Luebke JI, Turner TJ. 1995. Exocytotic calcium channels in mammalian central neurons. Trends Neurosci 18: 89-98.

Eliasson L, Abdulkader F, Braun M, Galvanovskis J, Hoppa MB, Rorsman P. 2008. Novel aspects of the molecular mechanisms controlling insulin secretion. J Physiol 586: 3313-3324.

Ellis SB, Williams ME, Ways NR, Brenner R, Sharp AH, Leung AT, Campbell KP, McKenna E, Koch WJ, Hui A, et al. 1988. Sequence and expression of mRNAs encoding the $\alpha 1$ and $\alpha 2$ subunits of a DHP-sensitive calcium channel. Science 241: 1661-1664.

Emrick MA, Sadilek M, Konoki K, Catterall WA. 2010. $\beta$-adrenergic-regulated phosphorylation of the skeletal muscle $\mathrm{Ca}_{\mathrm{V}} 1.1$ channel in the fight-or-flight response. Proc Natl Acad Sci 107: 18712-18717.

Erickson MG, Alseikhan BA, Peterson BZ, Yue DT. 2001. Preassociation of calmodulin with voltage-gated $\mathrm{Ca}^{2+}$ channels revealed by FRET in single living cells. Neuron 31: 973-985.

Ertel EA, Campbell KP, Harpold MM, Hofmann F, Mori Y, Perez-Reyes E Schwartz A, Snutch TP, Tanabe T, Birnbaumer L, et al. 2000. Nomenclature of voltage-gated calcium channels. Neuron 25: 533-535.

Fabiato A. 1983. Calcium-induced release of calcium from the cardiac sarcoplasmic reticulum. Am J Physiol 245: C1-C14.

Fedulova SA, Kostyuk PG, Veselovsky NS. 1985. Two types of calcium channels in the somatic membrane of newborn rat dorsal root ganglion neurones. J Physiol 359: 431-446.

Flavell SW, Greenberg ME. 2008. Signaling mechanisms linking neuronal activity to gene expression and plasticity of the nervous system. Annu Rev Neurosci 31: 563-590.

Flockerzi V, Oeken HJ, Hofmann F, Pelzer D, Cavalie A, Trautwein W. 1986. Purified dihydropyridine-binding site from skeletal muscle $t$-tubules is a functional calcium channel. Nature 323: 66-68.

Forsythe ID, Tsujimoto T, Barnes-Davies M, Cuttle MF, Takahashi T. 1998. Inactivation of presynaptic calcium current contributes to synaptic depression at a fast central synapse. Neuron 20: 797-807.

Fraser IDC, Tavalin SJ, Lester LB, Langeberg LK, Westphal AM, Dean RA, Marrion NV, Scott JD. 1998. A novel lipid-anchored A-kinase anchoring protein facilitates cAMP-responsive membrane events. EMBO J 17: 2261-2272.

Fuller MD, Emrick MA, Sadilek M, Scheuer T, Catterall WA. 2010. Molecular mechanism of calcium channel regulation in the fight-or-flight response. Sci Signal 3: ra70.

Gao T, Cuadra AE, Ma H, Bunemann M, Gerhardstein BL, Cheng T, Eick RT, Hosey MM. 2001. C-terminal fragments of the $\alpha 1 \mathrm{C}\left(\mathrm{Ca}_{\mathrm{v}} 1.2\right)$ subunit associate with and regulate L-type calcium channels containing C-terminaltruncated $\alpha 1 C$ subunits. J Biol Chem 276: 21089-21097.

Garcia DE, Li B, Garcia-Ferreiro RE, Hernández-Ochoa EO, Yan K, Gautam N, Catterall WA, Mackie K, Hille B. 1998 G-protein $\beta$ subunit specificity in the fast membranedelimited inhibition of $\mathrm{Ca}^{2+}$ channels. J Neurosci 18: 9163-9170. 
Voltage-Gated Calcium Channels

Gerhardstein BL, Gao T, Bunemann M, Puri TS, Adair A, Ma H, Hosey MM. 2000. Proteolytic processing of the C terminus of the $\alpha 1 \mathrm{C}$ subunit of L-type calcium channels and the role of a proline-rich domain in membrane tethering of proteolytic fragments. J Biol Chem 275: 8556-8563.

Gomez-Ospina N, Tsuruta F, Barreto-Chang O, Hu L, Dolmetsch R. 2006. The C terminus of the L-type voltagegated calcium channel $\mathrm{Ca}_{\mathrm{V}} 1.2$ encodes a transcription factor. Cell 127: 591-606.

Gray PC, Tibbs VC, Catterall WA, Murphy BJ. 1997. Identification of a $15-\mathrm{kDa}$ cAMP-dependent protein kinaseanchoring protein associated with skeletal muscle L-type calcium channels. J Biol Chem 272: 6297-6302.

Gray PC, Johnson BD, Westenbroek RE, Hays LG, Yates JR3rd, Scheuer T, Catterall WA, Murphy BJ. 1998. Primary structure and function of an A kinase anchoring protein associated with calcium channels. Neuron 20: 1017-1026.

Gurnett CA, De Waard M, Campbell KP. 1996. Dual function of the voltage-dependent $\mathrm{Ca}^{2+}$ channel $\alpha 2 \delta$ subunit in current stimulation and subunit interaction. Neuron 16: $431-440$.

Haase H, Bartel S, Karczewski P, Morano I, Krause EG. 1996. In-vivo phosphorylation of the cardiac L-type calcium channel $\beta$ subunit in response to catecholamines. Mol Cell Biochem 163-164: 99-106.

Haeseleer F, Palczewski K. 2002. Calmodulin and calciumbinding proteins: Variations on a theme. Adv Exp Med Biol 514: 303-317.

Hagiwara S, Ozawa S, Sand O. 1975. Voltage clamp analysis of two inward current mechanisms in the egg cell membrane of a starfish. J Gen Physiol 65: 617-644.

Heinemann SH, Terlau H, Stühmer W, Imoto K, Numa S. 1992. Calcium channel characteristics conferred on the sodium channel by single mutations. Nature 356: 441-443.

Hell JW, Westenbroek RE, Warner C, Ahlijanian MK, Prystay W, Gilbert MM, Snutch TP, Catterall WA. 1993a. Identification and differential subcellular localization of the neuronal class $\mathrm{C}$ and class D L-type calcium channel a1 subunits. J Cell Biol 123: 949-962.

Hell JW, Yokoyama CT, Wong ST, Warner C, Snutch TP, Catterall WA. 1993b. Differential phosphorylation of two size forms of the neuronal class C L-type calcium channel $\alpha 1$ subunit. J Biol Chem 268: 19451-19457.

Hell JW, Westenbroek RE, Breeze LJ, Wang KKW, Chavkin C, Catterall WA. 1996. N-methyl-D-aspartate receptorinduced proteolytic conversion of postsynaptic class $\mathrm{C}$ L-type calcium channels in hippocampal neurons. Proc Natl Acad Sci 93: 3362-3367.

Herlitze S, Garcia DE, Mackie K, Hille B, Scheuer T, Catterall WA. 1996. Modulation of calcium channels by $\mathrm{G}$ protein By subunits. Nature 380: 258-262.

Herlitze S, Hockerman GH, Scheuer T, Catterall WA. 1997. Molecular determinants of inactivation and G protein modulation in the intracelular loop connecting domains I and II of the calcium channel $\alpha 1$ A subunit. Proc Natl Acad Sci 94: 1512-1516.

Hille B. 1994. Modulation of ion-channel function by Gprotein-coupled receptors. Trends Neurosci 17: 531-536.
Hockerman GH, Peterson BZ, Johnson BD, Catterall WA. 1997a. Molecular determinants of drug binding and action on L-type calcium channels. Annu Rev Pharmacol Toxicol 37: 361-396.

Hockerman GH, Peterson BZ, Sharp E, Tanada TN, Scheuer T, Catterall WA. 1997b. Construction of a high-affinity receptor site for dihydropyridine agonists and antagonists by single amino acid substitutions in a non-L-type calcium channel. Proc Natl Acad Sci 94: 14906-14911.

Hofmann F, Biel M, Flockerzi V. 1994. Molecular basis for calcium channel diversity. Апnи Rev Neurosci 17: 399-418.

Hosey MM, Barhanin J, Schmid A, Vandaele S, Ptasienski J, O'Callahan C, Cooper C, Lazdunski M. 1987. Photoaffinity labelling and phosphorylation of a 165 kilodalton peptide associated with dihydropyridine and phenylalkylamine-sensitive calcium channels. Biochem Biophys Res Commun 147: 1137-1145.

Hulme JT, Ahn M, Hauschka SD, Scheuer T, Catterall WA. 2002. A novel leucine zipper targets AKAP15 and cyclic AMP-dependent protein kinase to the $\mathrm{C}$ terminus of the skeletal muscle calcium channel and modulates its function. J Biol Chem 277: 4079-4087.

Hulme JT, Lin TW, Westenbroek RE, Scheuer T, Catterall WA. 2003. $\beta$-adrenergic regulation requires direct anchoring of PKA to cardiac $\mathrm{Ca}_{\mathrm{V}} 1.2$ channels via a leucine zipper interaction with A kinase-anchoring protein 15. Proc Natl Acad Sci 100: 13093-13098.

Hulme JT, Konoki K, Lin TW, Gritsenko MA, Camp DG 2nd, Bigelow DJ, Catterall WA. 2005. Sites of proteolytic processing and noncovalent association of the distal C-terminal domain of $\mathrm{Ca}_{\mathrm{V}} 1.1$ channels in skeletal muscle. Proc Natl Acad Sci 102: 5274-5279.

Hulme JT, Westenbroek RE, Scheuer T, Catterall WA. 2006a. Phosphorylation of serine 1928 in the distal C-terminal of cardiac $\mathrm{Ca}_{\mathrm{v}} 1.2$ channels during $\beta$-adrenergic regulation. Proc Natl Acad Sci 103: 16574-16579.

Hulme JT, Yarov-Yarovoy V, Lin TW-C, Scheuer T, Catterall WA. 2006b. Autoinhibitory control of the $\mathrm{Ca}_{\mathrm{v}} 1.2$ channel by its proteolytically cleaved distal C-terminal domain. J Physiol (Lond) 576: 87-102.

Ikeda SR. 1996. Voltage-dependent modulation of N-type calcium channels by $G$-protein $\beta / \gamma$ subunits. Nature 380: $255-258$.

Ikeda SR, Dunlap K. 1999. Voltage-dependent modulation of N-type calcium channels: Role of G protein subunits. Adv Second Messenger Phosphoprotein Res 33: 131-151.

Jay SD, Ellis SB, McCue AF, Williams ME, Vedvick TS, Harpold MM, Campbell KP. 1990. Primary structure of the $\gamma$ subunit of the DHP-sensitive calcium channel from skeletal muscle. Science 248: 490-492.

Jenkins MA, Christel CJ, Jiao Y, Abiria S, Kim KY, Usachev YM, Obermair GJ, Colbran RJ, Lee A. 2010. $\mathrm{Ca}^{2+}$. dependent facilitation of $\mathrm{Ca}_{\mathrm{v}} 1.3 \mathrm{Ca}^{2+}$ channels by densin and $\mathrm{Ca}^{2+} /$ calmodulin-dependent protein kinase II. J Neurosci 30: 5125-5135.

Jiang X, Lautermilch NJ, Watari H, Westenbroek RE, Scheuer T, Catterall WA. 2008. Modulation of $\mathrm{Ca}_{\mathrm{v}} 2.1$ channels by $\mathrm{Ca}^{2+} /$ calmodulin-dependent protein kinase II bound to the C-terminal domain. Proc Natl Acad Sci 105: $341-346$. 
W.A. Catterall

Johnson BD, Scheuer T, Catterall WA. 1994. Voltagedependent potentiation of L-type $\mathrm{Ca}^{2+}$ channels in skeletal muscle cells requires anchored cAMP-dependent protein kinase. Proc Natl Acad Sci 91: 11492-11496.

Johnson BD, Brousal JP, Peterson BZ, Gallombardo PA, Hockerman GH, Lai Y, Scheuer T, Catterall WA. 1997. Modulation of the cloned skeletal muscle L-type $\mathrm{Ca}^{2+}$ channel by anchored cAMP-dependent protein kinase. J Neurosci 17: 1243-1255.

Jones LP, Patil PG, Snutch TP, Yue DT. 1997. G-protein modulation of N-type calcium channel gating current in human embryonic kidney cells (HEK 293). J Physiol (Lond) 498: 601-610.

Keith RK, Poage RE, Yokoyama CT, Catterall WA, Meriney SD. 2007. Bidirectional modulation of transmitter release by calcium channel/syntaxin interactions in vivo. J Neurosci 27: 265-269.

Kim D, Song I, Keum S, Lee T, Jeong MJ, Kim SS, McEnery MW, Shin HS. 2001. Lack of the burst firing of thalamocortical relay neurons and resistance to absence seizures in mice lacking $\alpha 1 \mathrm{G}$ T-type $\mathrm{Ca}^{2+}$ channels. Neuron 31: 35-45.

Kiyonaka S, Wakamori M, Miki T, Uriu Y, Nonaka M, Bito H, Beedle AM, Mori E, Hara Y, De Waard M, et al 2007. RIM1 confers sustained activity and neurotransmitter vesicle anchoring to presynaptic calcium channels. Nat Neurosci 10: 691-701.

Klugbauer N, Lacinová L, Marais E, Hobom M, Hofmann F. 1999. Molecular diversity of the calcium channel $\alpha 2 \delta$ subunit. J Neurosci 19: 684-691.

Klugbauer N, Dai S, Specht V, Lacinova L, Marais E, Bohn G, Hofmann F. 2000. A family of $\gamma$-like calcium channel subunits. FEBS Lett 470: 189-197.

Kollmar R, Montgomery LG, Fak J, Henry LJ, Hudspeth AJ. 1997. Predominance of the $\alpha 1 \mathrm{D}$ subunit in L-type voltage-gated $\mathrm{Ca}^{2+}$ channels of hair cells in the chicken's cochlea. Proc Natl Acad Sci 94: 14883-14888.

Kuniyasu A, Oka K, Ide-Yamada T, Hatanaka Y, Abe T, Nakayama H, Kanaoka Y. 1992. Structural characterization of the dihydropyridine receptor-linked calcium channel from porcine heart. J Biochem (Tokyo) 112: $235-242$.

Lacerda AE, Kim HS, Ruth P, Perez-Reyes E, Flockerzi V, Hofmann F, Birnbaumer L, Brown AM. 1991. Normalization of current kinetics by interaction between the $\alpha 1$ and $\beta$ subunits of the skeletal muscle dihydropyridinesensitive calcium channel. Nature 352: 527-530.

Lautermilch NJ, Few AP, Scheuer T, Catterall WA. 2005. Modulation of $\mathrm{Ca}_{\mathrm{V}} 2.1$ channels by the neuronal calciumbinding protein visinin-like protein-2. J Neurosci 25: 7062-7070.

Lee A, Wong ST, Gallagher D, Li B, Storm DR, Scheuer T, Catterall WA. 1999. $\mathrm{Ca}^{2+} /$ calmodulin binds to and modulates P/Q-type calcium channels. Nature 399: 155-159.

Lee A, Scheuer T, Catterall WA. 2000. Calcium/calmodulin dependent inactivation and facilitation of $\mathrm{P} / \mathrm{Q}$-type calcium channels. J Neurosci 20: 6830-6838.

Lee A, Westenbroek RE, Haeseleer F, Palczewski K, Scheuer T, Catterall WA. 2002. Differential modulation of $\mathrm{Ca}_{\mathrm{V}} 2.1$ channels by calmodulin and $\mathrm{Ca}^{2+}$-binding protein 1. Nat Neurosci 5: 210-217.
Lee A, Zhou H, Scheuer T, Catterall WA. 2003. Molecular determinants of $\mathrm{Ca}^{2+} /$ calmodulin-dependent regulation of $\mathrm{Ca}_{\mathrm{v}} 2.1$ channels. Proc Natl Acad Sci 100: 16059-16064.

Lee J, Kim D, Shin HS. 2004. Lack of $\delta$ waves and sleep disturbances during non-rapid eye movement sleep in mice lacking $\alpha 1 G$ subunit of T-type calcium channels. Proc Natl Acad Sci 101: 18195-18199.

Letts VA, Felix R, Biddlecome GH, Arikkath J, Mahaffey CL, Valenzuela A, Bartlett IFS, Mori Y, Campbell KP, Frankel WN. 1998. The mouse stargazer gene encodes a neuronal calcium-channel $\gamma$ subunit. Nature Genet 19: 340-347.

Leung AT, Imagawa T, Campbell KP. 1987. Structural characterization of the 1,4-dihydropyridine receptor of the voltage-dependent calcium channel from rabbit skeletal muscle. Evidence for two distinct high molecular weight subunits. J Biol Chem 262: 7943-7946.

Li B, Zhong H, Scheuer T, Catterall WA. 2004. Functional role of a C-terminal $\mathrm{G} \beta \gamma$-binding domain of $\mathrm{Ca}_{\mathrm{v}} 2.2$ channels. Mol Pharmacol 66: 761-769.

Liu H, De Waard M, Scott VES, Gurnett CA, Lennon VA, Campbell KP. 1996. Identification of three subunits of the high affinity omega-conotoxin MVIIC-sensitive calcium channel. J Biol Chem 271: 13804-13810.

Llinás R, Yarom Y. 1981. Electrophysiology of mammalian inferior olivary neurones in vitro. Different types of voltage-dependent ionic conductances. J Physiol (Lond) 315: $569-584$.

Llinás RR, Sugimori M, Cherksey B. 1989. Voltagedependent calcium conductances in mammalian neurons. The P channel. Ann NY Acad Sci 560: 103-111.

Llinás R, Sugimori M, Hillman DE, Cherksey B. 1992. Distribution and functional significance of the P-type, voltage-dependent calcium channels in the mammalian central nervous system. Trends Neurosci 15: 351-355.

Mangoni ME, Traboulsie A, Leoni AL, Couette B, Marger L, Le Quang K, Kupfer E, Cohen-Solal A, Vilar J, Shin HS, et al. 2006. Bradycardia and slowing of the atrioventricular conduction in mice lacking $\mathrm{Ca}_{\mathrm{V}} 3.1 / \alpha 1 \mathrm{G}$ T-type calcium channels. Circ Res 98: 1422-1430.

Marcantoni A, Baldelli P, Hernandez-Guijo JM, Comunanza V, Carabelli V, Carbone E. 2007. L-type calcium channels in adrenal chromaffin cells: Role in pace-making and secretion. Cell Calcium 42: 397-408.

Marchetti C, Carbone E, Lux HD. 1986. Effects of dopamine and noradrenaline on Ca channels of cultured sensory and sympathetic neurons of chick. Pflugers Arch 406: 104-111.

Martin-Moutot N, Leveque C, Sato K, Kato R, Takahashi M, Seagar M. 1995. Properties of omega conotoxin MVIIC receptors associated with $\alpha 1 \mathrm{~A}$ calcium channel subunits in rat brain. FEBS Lett 366: 21-25.

McDonald TF, Pelzer S, Trautwein W, Pelzer DJ. 1994. Regulation and modulation of calcium channels in cardiac, skeletal, and smooth muscle cells. Physiol Rev 74: 365-507.

McEnery MW, Snowman AM, Sharp AH, Adams ME, Snyder SH. 1991. Purified omega-conotoxin GVIA receptor of rat brain resembles a dihydropyridine-sensitive L-type calcium channel. Proc Natl Acad Sci 88: 11095-11099. 
Voltage-Gated Calcium Channels

Mintz IM, Adams ME, Bean BP. 1992. P-type calcium channels in rat central and peripheral neurons. Neuron 9: 85-95.

Mitterdorfer J, Froschmayr M, Grabner M, Moebius FF, Glossmann H, Striessnig J. 1996. Identification of PKA phosphorylation sites in the carboxyl terminus of L-type calcium channel $\alpha-1$ subunits. Biochemistry 35: 9400-9406.

Mochida S, Sheng ZH, Baker C, Kobayashi H, Catterall WA. 1996. Inhibition of neurotransmission by peptides containing the synaptic protein interaction site of N-type $\mathrm{Ca}^{2+}$ channels. Neuron 17: 781-788.

Mochida S, Few AP, Scheuer T, Catterall WA. 2008. Regulation of presynaptic $\mathrm{Ca}_{\mathrm{V}} 2.1$ channels by $\mathrm{Ca}^{2+}$ sensor proteins mediates short-term synaptic plasticity. Neuron $\mathbf{5 7}$ 210-216.

Mori Y, Friedrich T, Kim MS, Mikami A, Nakai J, Ruth P, Bosse E, Hofmann F, Flockerzi V, Furuichi T, et al. 1991. Primary structure and functional expression from complementary DNA of a brain calcium channel. Nature 350: $398-402$.

Nakai J, Dirksen RT, Nguyen HT, Pessah IN, Beam KG, Allen PD. 1996. Enhanced dihydropyridine receptor channel activity in the presence of ryanodine receptor. Nature 380: $72-75$.

Nakai J, Sekiguchi N, Rando TA, Allen PD, Beam KG. 1998. Two regions of the ryanodine receptor involved in coupling with L-type $\mathrm{Ca}^{2+}$ channels. J Biol Chem 273: 13403-13406.

Newcomb R, Szoke B, Palma A, Wang G, Chen XH, Hopkins W, Cong R, Miller J, Urge L, Tarczy-Hornoch K, et al. 1998. Selective peptide antagonist of the class $\mathrm{E}$ calcium channel from the venom of the tarantula Hysterocrates gigas. Biochemistry 37: 15353-15362.

Nicoll RA, Tomita S, Bredt DS. 2006. Auxiliary subunits assist AMPA-type glutamate receptors. Science 311: $1253-1256$.

Nowycky MC, Fox AP, Tsien RW. 1985. Three types of neuronal calcium channel with different calcium agonist sensitivity. Nature 316: 440-443.

Numa S, Tanabe T, Takeshima H, Mikami A, Niidome T, Nishimura S, Adams BA, Beam KG. 1990. Molecular insights into excitation-contraction coupling. Cold Spring Harb Symp Quant Biol 55: 1-7.

Olivera BM, Miljanich GP, Ramachandran J, Adams ME. 1994. Calcium channel diversity and neurotransmitter release: The omega-conotoxins and omega-agatoxins. Annu Rev Biochem 63: 823-867.

Oliveria SF, Dell'Acqua ML, Sather WA. 2007. AKAP79/150 anchoring of calcineurin controls neuronal L-type $\mathrm{Ca}^{2+}$ channel activity and nuclear signaling. Neuron 55: 261-275.

Osterrieder W, Brum G, Hescheler J, Trautwein W, Flockerzi V, Hofmann F. 1982. Injection of subunits of cyclic AMPdependent protein kinase into cardiac myocytes modulates $\mathrm{Ca}^{2+}$ current. Nature 298: 576-578.

Page KM, Stephens GJ, Berrow NS, Dolphin AC. 1997. The intracellular loop between domains I and II of the B-type calcium channel confers aspects of G-protein sensitivity to the E-type calcium channel. J Neurosci 17: 1330-1338.
Page KM, Cantí C, Stephens GJ, Berrow NS, Dolphin AC. 1998. Identification of the amino terminus of neuronal $\mathrm{Ca}^{2+}$ channel $\alpha 1$ subunits $\alpha 1 \mathrm{~B}$ and $\alpha 1 \mathrm{E}$ as an essential determinant of G-protein modulation. J Neurosci 18: 4815-4824.

Perez-Reyes E, Kim HS, Lacerda AE, Horne W, Wei XY, Rampe D, Campbell KP, Brown AM, Birnbaumer L. 1989. Induction of calcium currents by the expression of the $\alpha 1$ subunit of the dihydropyridine receptor from skeletal muscle. Nature 340: 233-236.

Perez-Reyes E, Cribbs LL, Daud A, Lacerda AE, Barclay J, Williamson MP, Fox M, Rees M, Lee JH. 1998. Molecular characterization of a neuronal low-voltage-activated T-type calcium channel. Nature 391: 896-900.

Peterson BZ, DeMaria CD, Yue DT. 1999. Calmodulin is the $\mathrm{Ca}^{2+}$ sensor for $\mathrm{Ca}^{2+}$-dependent inactivation of L-type calcium channels. Neuron 22: 549-558.

Pichler M, Cassidy TN, Reimer D, Haase H, Krause R, Ostler D, Striessnig J. 1997. $\beta$ subunit heterogeneity in neuronal L-type calcium channels. J Biol Chem 272: 13877-13882.

Pitt GS, Zuhlke RD, Hudmon A, Schulman H, Reuter H, Tsien RW. 2001. Molecular basis of calmodulin tethering and calcium-dependent inactivation of L-type calcium channels. J Biol Chem 276: 30794-30802.

Platzer J, Engel J, Schrott-Fischer A, Stephan K, Bova S, Chen H, Zheng H, Striessnig J. 2000. Congenital deafness and sinoatrial node dysfunction in mice lacking class D L-type $\mathrm{Ca}^{2+}$ channels. Cell 102: 89-97.

Pragnell M, De Waard M, Mori Y, Tanabe T, Snutch TP, Campbell KP. 1994. Calcium channel $\beta$ subunit binds to a conserved motif in the I-II cytoplasmic linker of the $\alpha 1$ subunit. Nature 368: $67-70$.

Puri TS, Gerhardstein BL, Zhao XL, Ladner MB, Hosey MM. 1997. Differential effects of subunit interactions on protein kinase A- and C-mediated phosphorylation of L-type calcium channels. Biochemistry 36: 9605-9615.

Qin N, Platano D, Olcese R, Stefani E, Birnbaumer L. 1997. Direct interaction of G $\beta \gamma$ with a C-terminal G $\beta \gamma$-binding domain of the $\mathrm{Ca}^{2+}$ channel $\alpha 1$ subunit is responsible for channel inhibition by $\mathrm{G}$ protein-coupled receptors. Proc Natl Acad Sci 94: 8866-8871.

Qin N, Olcese R, Bransby M, Lin T, Birnbaumer L. 1999. $\mathrm{Ca}^{2+}$ induced inhibition of the cardiac $\mathrm{Ca}^{2+}$ channel depends on calmodulin. Proc Natl Acad Sci 96: $2435-2438$

Randall A, Tsien RW. 1995. Pharmacological dissection of multiple types of calcium channel currents in rat cerebellar granule neurons. J Neurosci 15: 2995-3012.

Rettig J, Sheng Z-H, Kim DK, Hodson CD, Snutch TP, Catterall WA. 1996. Isoform-specific interaction of the $\alpha 1 \mathrm{~A}$ subunits of brain $\mathrm{Ca}^{2+}$ channels with the presynaptic proteins syntaxin and SNAP-25. Proc Natl Acad Sci 93: $7363-7368$.

Rettig J, Heinemann C, Ashery U, Sheng ZH, Yokoyama CT, Catterall WA, Neher E. 1997. Alteration of $\mathrm{Ca}^{2+}$ dependence of neurotransmitter release by disruption of $\mathrm{Ca}^{2+}$ channel/syntaxin interaction. J Neurosci 17: 6647-6656.

Reuter H. 1979. Properties of two inward membrane currents in the heart. Annu Rev Physiol 41: 413-424.

Reuter H. 1983. Calcium channel modulation by neurotransmitters, enzymes and drugs. Nature 301: 569-574. 
W.A. Catterall

Reuter H, Scholz H. 1977. The regulation of calcium conductance of cardiac muscle by adrenaline. J Physiol 264: 49-62.

Rotman EI, De Jongh KS, Florio V, Lai Y, Catterall WA. 1992. Specific phosphorylation of a $\mathrm{COOH}$-terminal site on the full-length form of the $\alpha 1$ subunit of the skeletal muscle calcium channel by cAMP-dependent protein kinase. J Biol Chem 267: 16100-16105.

Rotman EI, Murphy BJ, Catterall WA. 1995. Sites of selective cAMP-dependent phosphorylation of the L-type calcium channel $\alpha 1$ subunit from intact rabbit skeletal muscle myotubes. J Biol Chem 270: 16371-16377.

Ruth P, Röhrkasten A, Biel M, Bosse E, Regulla S, Meyer HE, Flockerzi V, Hofmann F. 1989. Primary structure of the $\beta$ subunit of the DHP-sensitive calcium channel from skeletal muscle. Science 245: 1115-1118.

Sather WA, McCleskey EW. 2003. Permeation and selectivity in calcium channels. Annu Rev Physiol 65: 133-159.

Schneider T, Hofmann F. 1988. The bovine cardiac receptor for calcium channel blockers is a $195-\mathrm{kDa}$ protein. Eur J Biochem 174: 369-375.

Schroder E, Byse M, Satin J. 2009. L-type calcium channel C terminus autoregulates transcription. Circ Res 104: 1373-1381.

Sculptoreanu A, Scheuer T, Catterall WA. 1993. Voltagedependent potentiation of L-type $\mathrm{Ca}^{2+}$ channels due to phosphorylation by cAMP-dependent protein kinase. Nature 364: 240-243.

Serysheva II, Ludtke SJ, Baker MR, Chiu W, Hamilton SL. 2002. Structure of the voltage-gated L-type $\mathrm{Ca}^{2+}$ channel by electron cryomicroscopy. Proc Natl Acad Sci 99: 10370-10375.

Sheng Z-H, Rettig J, Takahashi M, Catterall WA. 1994. Identification of a syntaxin-binding site on N-type calcium channels. Neuron 13: 1303-1313.

Sheng Z-H, Rettig J, Cook T, Catterall WA. 1996. Calciumdependent interaction of N-type calcium channels with the synaptic core-complex. Nature 379: 451-454.

Sheng Z-H, Yokoyama C, Catterall WA. 1997. Interaction of the synprint site of $\mathrm{N}$-type $\mathrm{Ca}^{2+}$ channels with the $\mathrm{C} 2 \mathrm{~B}$ domain of synaptotagmin I. Proc Natl Acad Sci 94: 5405-5410.

Singer D, Biel M, Lotan I, Flockerzi V, Hofmann F, Dascal N. 1991. The roles of the subunits in the function of the calcium channel. Science 253: 1553-1557.

Singh A, Hamedinger D, Hoda JC, Gebhart M, Koschak A, Romanin C, Striessnig J. 2006. C-terminal modulator controls $\mathrm{Ca}^{2+}$-dependent gating of $\mathrm{Ca}_{\mathrm{v}} 1.4 \mathrm{~L}$-type $\mathrm{Ca}^{2+}$ channels. Nat Neurosci 9: 1108-1116.

Singh A, Gebhart M, Fritsch R, Sinnegger-Brauns MJ, Poggiani C, Hoda JC, Engel J, Romanin C, Striessnig J, Koschak A. 2008. Modulation of voltage- and $\mathrm{Ca}^{2+}$ dependent gating of $\mathrm{Ca}_{\mathrm{V}} 1.3 \mathrm{~L}$-type calcium channels by alternative splicing of a C-terminal regulatory domain. J Biol Chem 283: 20733-20744.

Snutch TP, Reiner PB. 1992. Calcium channels: Diversity of form and function. Curr Opin Neurobiol 2: 247-253.

Song I, Kim D, Choi S, Sun M, Kim Y, Shin HS. 2004. Role of the $\alpha 1 \mathrm{G}$ T-type calcium channel in spontaneous absence seizures in mutant mice. J Neurosci 24: 5249-5257.
Soong TW, Stea A, Hodson CD, Dubel SJ, Vincent SR, Snutch TP. 1994. Structure and functional expression of a member of the low voltage-activated calcium channel family. Science 260: 1133-1136.

Starr TVB, Prystay W, Snutch TP. 1991. Primary structure of a calcium channel that is highly expressed in the rat cerebellum. Proc Natl Acad Sci 88: 5621-5625.

Striessnig J, Knaus HG, Grabner M, Moosburger K, Seitz W, Lietz H, Glossmann H. 1987. Photoaffinity labelling of the phenylalkylamine receptor of the skeletal muscle transverse-tubule calcium channel. FEBS Lett 212: 247-253.

Striessnig J, Bolz HJ, Koschak A. 2010. Channelopathies in $\mathrm{Ca}_{\mathrm{v}} 1.1, \mathrm{Ca}_{\mathrm{v}} 1.3$, and $\mathrm{Ca}_{\mathrm{v}} 1.4$ voltage-gated L-type $\mathrm{Ca}^{2+}$ channels. Pflugers Arch 460: 361-374.

Sudhof TC. 1995. The synaptic vesicle cycle: A cascade of protein-protein interactions. Nature 375: 645-653.

Sudhof TC. 2004. The synaptic vesicle cycle. Annu Rev Neurosci 27: 509-547.

Takahashi M, Seagar MJ, Jones JF, Reber BF, Catterall WA. 1987. Subunit structure of dihydropyridine-sensitive calcium channels from skeletal muscle. Proc Natl Acad Sci 84: 5478-5482.

Tanabe T, Takeshima H, Mikami A, Flockerzi V, Takahashi H, Kangawa K, Kojima M, Matsuo H, Hirose T, Numa S. 1987. Primary structure of the receptor for calcium channel blockers from skeletal muscle. Nature 328: 313-318.

Tanabe T, Beam KG, Adams BA, Niidome T, Numa S. 1990. Regions of the skeletal muscle dihydropyridine receptor critical for excitation-contraction coupling. Nature 346: $567-569$.

Tanabe T, Mikami A, Niidome T, Numa S, Adams BA, Beam KG. 1993. Structure and function of voltage-dependent calcium channels from muscle. Ann NY Acad Sci 707: $81-86$.

Tobi D, Wiser O, Trus M, Atlas D. 1999. N-type voltagesensitive calcium channel interacts with syntaxin, synaptotagmin and SNAP-25 in a multiprotein complex. Receptor Channel 6: 89-98.

Tottene A, Moretti A, Pietrobon D. 1996. Functional diversity of P-type and R-type calcium channels in rat cerebellar neurons. J Neurosci 16: 6353-6363.

Tsien RW. 1973. Adrenaline-like effects of intracellular iontophoresis of cyclic AMP in cardiac Purkinje fibres. Nat New Biol 245: 120-122.

Tsien RW. 1983. Calcium channels in excitable cell membranes. Annu Rev Physiol 45: 341-358.

Tsien RW, Bean BP, Hess P, Lansman JB, Nilius B, Nowycky MC. 1986. Mechanisms of calcium channel modulation by $\beta$-adrenergic agents and dihydropyridine calcium agonists. J Mol Cell Cardiol 18: 691-710.

Tsien RW, Lipscombe D, Madison DV, Bley KR, Fox AP. 1988. Multiple types of neuronal calcium channels and their selective modulation. Trends Neurosci 11: 431-438.

Van Petegem F, Clark KA, Chatelain FC, Minor DL Jr. 2004. Structure of a complex between a voltage-gated calcium channel $\beta$ subunit and an $\alpha$ subunit domain. Nature 429: 671-675. 
Voltage-Gated Calcium Channels

Wang MC, Velarde G, Ford RC, Berrow NS, Dolphin AC, Kitmitto A. 2002. 3D structure of the skeletal muscle dihydropyridine receptor. J Mol Biol 323: 85-98.

Wei XNA, Lacerda AE, Olcese R, Stefani E, Perez-Reyes E, Birnbaumer L. 1994. Modification of $\mathrm{Ca}^{2+}$ channel activity by deletions at the carboxyl terminus of the cardiac $\alpha 1$ subunit. J Biol Chem 269: 1635-1640.

Welsby PJ, Wang H, Wolfe JT, Colbran RJ, Johnson ML, Barrett PQ. 2003. A mechanism for the direct regulation of T-type calcium channels by $\mathrm{Ca}^{2+} /$ calmodulindependent kinase II. J Neurosci 23: 10116-10121.

Westenbroek RE, Ahlijanian MK, Catterall WA. 1990. Clustering of L-type $\mathrm{Ca}^{2+}$ channels at the base of major dendrites in hippocampal pyramidal neurons. Nature 347: $281-284$.

Wheeler DG, Barrett CF, Groth RD, Safa P, Tsien RW. 2008. CaMKII locally encodes L-type channel activity to signal to nuclear CREB in excitation-transcription coupling. J Cell Biol 183: 849-863.

Williams ME, Brust PF, Feldman DH, Patthi S, Simerson S Maroufi A, McCue AF, Velicelebi G, Ellis SB, Harpold MM. 1992. Structure and functional expression of an omega-conotoxin-sensitive human N-type calcium channel. Science 257: 389-395.

Wiser O, Bennett MK, Atlas D. 1996. Functional interaction of syntaxin and SNAP-25 with voltage-sensitive L- and N-type $\mathrm{Ca}^{2+}$ channels. EMBO J 15: 4100-4110.

Wiser O, Tobi D, Trus M, Atlas D. 1997. Synaptotagmin restores kinetic properties of a syntaxin-associated Ntype voltage sensitive calcium channel. FEBS Lett 404: 203-207.

Witcher DR, De Waard M, Kahl SD, Campbell KP. 1995a. Purification and reconstitution of N-type calcium channel complex from rabbit brain. Method Enzymol 238: 335-348.

Witcher DR, De Waard M, Liu H, Pragnell M, Campbell KP. $1995 \mathrm{~b}$. Association of native calcium channel $\beta$ subunits with the $\alpha 1$ subunit interaction domain. J Biol Chem 270: 18088-18093.

Wolf M, Eberhart A, Glossmann H, Striessnig J, Grigorieff N. 2003. Visualization of the domain structure of an L-type $\mathrm{Ca}^{2+}$ channel using electron cryo-microscopy. J Mol Biol 332: 171-182.
Wolfe JT, Wang H, Howard J, Garrison JC, Barrett PQ. 2003. T-type calcium channel regulation by specific G-protein By subunits. Nature 424: 209-213.

Yang SN, Berggren PO. 2006. The role of voltage-gated calcium channels in pancreatic $\beta$-cell physiology and pathophysiology. Endocr Rev 27: 621-676.

Yao J, Davies LA, Howard JD, Adney SK, Welsby PJ, Howell N, Carey RM, Colbran RJ, Barrett PQ. 2006. Molecular basis for the modulation of native T-type $\mathrm{Ca}^{2+}$ channels in vivo by $\mathrm{Ca}^{2+} /$ calmodulin-dependent protein kinase II. J Clin Invest 116: 2403-2412.

Yi BA, Jan LY. 2000. Taking apart the gating of voltage-gated potassium channels. Neuron 27: 423-425.

Yokoyama CT, Sheng Z-H, Catterall WA. 1997. Phosphorylation of the synaptic protein interaction site on N-type calcium channels inhibits interactions with SNARE proteins. J Neurosci 17: 6929-6938.

Yokoyama CT, Myers SJ, Fu J, Mockus SM, Scheuer T, Catterall WA. 2005. Mechanism of SNARE protein binding and regulation of $\mathrm{Ca}_{\mathrm{v}} 2$ channels by phosphorylation of the synaptic protein interaction site. Mol Cell Neurosci 28: $1-17$.

Yu FH, Yarov-Yarovoy V, Gutman GA, Catterall WA. 2005. Overview of molecular relationships in the voltage-gated ion channel superfamily. Pharmacol Rev 57: 387-395.

Zamponi GW, Bourinet E, Nelson D, Nargeot J, Snutch TP. 1997. Crosstalk between $G$ proteins and protein kinase $C$ mediated by the calcium channel $\alpha 1$ subunit. Nature 385: $442-446$.

Zhang JF, Ellinor PT, Aldrich RW, Tsien RW. 1996. Multiple structural elements in voltage-dependent $\mathrm{Ca}^{2+}$ channels support their inhibition by G proteins. Neuron 17: 991-1003.

Zhong H, Yokoyama C, Scheuer T, Catterall WA. 1999. Reciprocal regulation of P/Q-type calcium channels by SNAP-25, syntaxin and synaptotagmin. Nat Neurosci 2: 939-941.

Zühlke RD, Pitt GS, Deisseroth K, Tsien RW, Reuter H. 1999. Calmodulin supports both inactivation and facilitation of L-type calcium channels. Nature 399: $159-162$. 


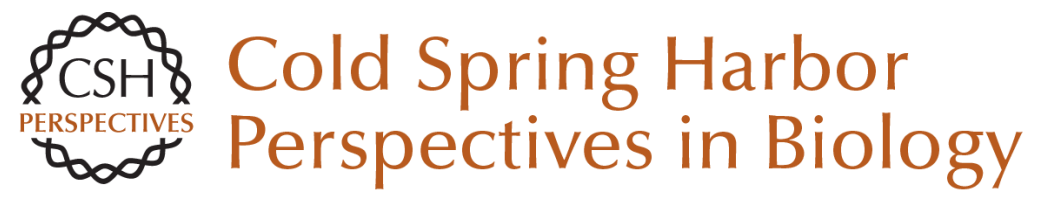

\title{
Voltage-Gated Calcium Channels
}

\author{
William A. Catterall
}

Cold Spring Harb Perspect Biol 2011; doi: 10.1101/cshperspect.a003947 originally published online July 11,2011

\section{Subject Collection Calcium Signaling}

The Endoplasmic Reticulum-Plasma Membrane Junction: A Hub for Agonist Regulation of $\mathrm{Ca}^{2+}$ Entry

Hwei Ling Ong and Indu Suresh Ambudkar

Calcium-Handling Defects and Neurodegenerative Disease

Sean Schrank, Nikki Barrington and Grace E. Stutzmann

Lysosomal $\mathrm{Ca}^{2+}$ Homeostasis and Signaling in Health and Disease

Emyr Lloyd-Evans and Helen Waller-Evans

\section{$\mathrm{Ca}^{2+}$ Signaling in Exocrine Cells}

Malini Ahuja, Woo Young Chung, Wei-Yin Lin, et al.

Functional Consequences of Calcium-Dependent Synapse-to-Nucleus Communication: Focus on Transcription-Dependent Metabolic Plasticity Anna M. Hagenston, Hilmar Bading and Carlos Bas-Orth

Identifying New Substrates and Functions for an Old Enzyme: Calcineurin Jagoree Roy and Martha S. Cyert

Fundamentals of Cellular Calcium Signaling: A Primer

Martin D. Bootman and Geert Bultynck
Primary Active $\mathrm{Ca}^{2+}$ Transport Systems in Health and Disease Jialin Chen, Aljona Sitsel, Veronick Benoy, et al.

Signaling through $\mathrm{Ca}^{2+}$ Microdomains from Store-Operated CRAC Channels Pradeep Barak and Anant B. Parekh

Structural Insights into the Regulation of $\mathrm{Ca}^{2+}$ /Calmodulin-Dependent Protein Kinase II (CaMKII) Moitrayee Bhattacharyya, Deepti Karandur and John Kuriyan

Store-Operated Calcium Channels: From Function to Structure and Back Again Richard S. Lewis

Bcl-2-Protein Family as Modulators of $\mathrm{IP}_{3}$

Receptors and Other Organellar $\mathrm{Ca} 2+$ Channels Hristina Ivanova, Tim Vervliet, Giovanni Monaco, et al.

Calcium Signaling in Cardiomyocyte Function Guillaume Gilbert, Kateryna Demydenko, Eef Dries, et al.

Cytosolic $\mathrm{Ca}^{2+}$ Buffers Are Inherently $\mathrm{Ca}^{2+}$ Signal Modulators Beat Schwaller

For additional articles in this collection, see http://cshperspectives.cshlp.org/cgi/collection/

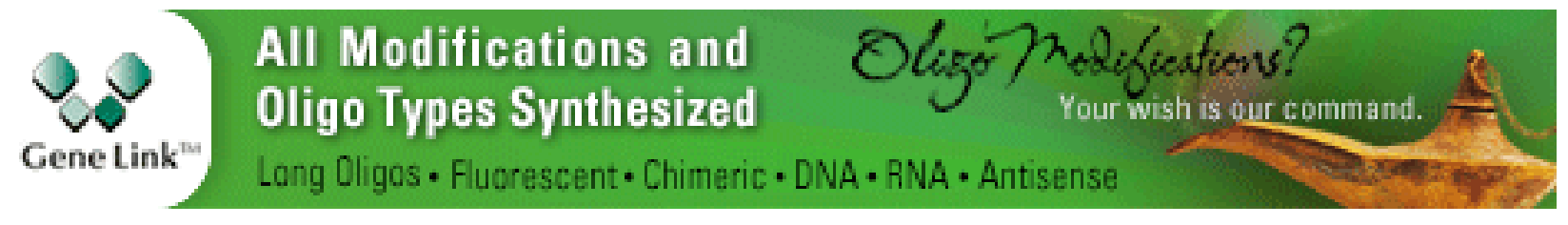

Copyright @ 2011 Cold Spring Harbor Laboratory Press; all rights reserved 
Role of Two-Pore Channels in Embryonic Development and Cellular Differentiation Sarah E. Webb, Jeffrey J. Kelu and Andrew L. Miller

\section{Organellar Calcium Handling in the Cellular \\ Reticular Network}

Wen-An Wang, Luis B. Agellon and Marek Michalak

For additional articles in this collection, see http://cshperspectives.cshlp.org/cgi/collection/

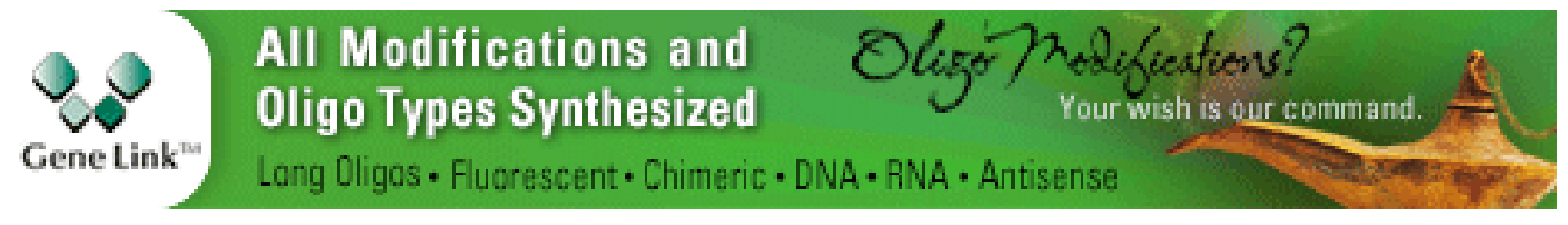

Copyright @ 2011 Cold Spring Harbor Laboratory Press; all rights reserved 